\title{
Improvement of Food Packaging- Related Properties of Whey Protein Isolate-Based Nanocomposite Films and Coatings by Addition of Montmorillonite Nanoplatelets
}

\author{
Markus Schmid ${ }^{1,2 *}$, Sarah Merzbacher ${ }^{1}$, Nicola Brzoska ${ }^{1}, K_{\text {Kerstin Müller }}{ }^{1}$ \\ and Marius Jesdinszki ${ }^{1}$
}

' TUM School of Life Sciences Weihenstephan, Technical University of Munich, Freising, Germany, ${ }^{2}$ Materials Development Department, Fraunhofer Institute for Process Engineering and Packaging IVV, Freising, Germany

\section{OPEN ACCESS}

Edited by: Jerome Claverie,

Université de Sherbrooke, Canada

Reviewed by:

$\mathrm{Xu} \mathrm{Li}$,

Institute of Materials Research and

Engineering ( $\left.A^{*} S T A R\right)$, Singapore

Valérie Heroguez,

Laboratoire de Chimie des Polymères Organiques CNRSUMR5629, France

*Correspondence: Markus Schmid markus.schmid@ivv.fraunhofer.de

Specialty section:

This article was submitted to Polymer Chemistry, a section of the journal

Frontiers in Materials

Received: 07 September 2017

Accepted: 23 October 2017

Published: 16 November 2017

Citation:

Schmid M, Merzbacher S, Brzoska N,

Müller K and Jesdinszki M (2017)

Improvement of Food PackagingRelated Properties of Whey Protein Isolate-Based Nanocomposite Films and Coatings by Addition of Montmorillonite Nanoplatelets.

Front. Mater. 4:35.

doi: 10.3389/fmats.2017.00035
In this study, the effects of the addition of montmorillonite (MMT) nanoplatelets on whey protein isolate (WPI)-based nanocomposite films and coatings were investigated. The main objective was the development of WPI-based MMT nanocomposites with enhanced barrier and mechanical properties. WPI-based nanocomposite cast films and coatings were prepared by dispersing 0\% (reference sample), 3, 6, 9\% (w/w protein) MMT, or, depending on the protein concentration, also 12 and 15\% (w/w protein) MMT into native WPI-based dispersions, followed by subsequent denaturation during the drying and curing process. The natural MMT nanofillers could be randomly dispersed into film-forming WPI-based nanodispersions, displaying good compatibility with the hydrophilic biopolymer matrix. As a result, by addition of 15\% (w/w protein) MMT into 10\% (w/w dispersion) WPI-based cast films or coatings, the oxygen permeability (OP) was reduced by $91 \%$ for glycerol-plasticized and $84 \%$ for sorbitol-plasticized coatings, water vapor transmission rate was reduced by $58 \%$ for sorbitol-plasticized cast films. Due to the addition of MMT nanofillers, the Young's modulus and tensile strength improved by 315 and 129\%, respectively, whereas elongation at break declined by $77 \%$ for glycerol-plasticized cast films. In addition, comparison of plasticizer type revealed that sorbitol-plasticized cast films were generally stiffer and stronger, but less flexible compared glycerol-plasticized cast films. Viscosity measurements demonstrated good processability and suitability for up-scaled industrial processes of native WPI-based nanocomposite dispersions, even at high-nanofiller loadings. These results suggest that the addition of natural MMT nanofillers into native WPI-based matrices to form nanocomposite films and coatings holds great potential to replace well-established, fossil-based packaging materials for at least certain applications such as oxygen barriers as part of multilayer flexible packaging films.

Keywords: whey protein isolate, nanocomposite, nanofiller, oxygen permeability, water vapor permeability, montmorillonite, coatings

\section{INTRODUCTION}

Edible films and coatings based on whey proteins show great potential to replace fossil-based plastics in certain applications, e.g., for oxygen-sensitive products, making whey proteins one of the most promising biopolymers in the field of packaging. Their relatively low oxygen permeability (OP), ability to form self-supporting films, as well as their abundancy and biodegradability all contribute to the great 
attention paid to whey proteins in recent years (Hong and Krochta, 2006; Sothornvit et al., 2009; Hammann and Schmid, 2014; Schmid et al., 2015; Zink et al., 2016). However, compared to respective petroleum-based barrier plastics, the barrier properties of whey proteins against gases, e.g., oxygen or carbon dioxide, and water vapor are not effective enough to be competitive. This can particularly be attributed to their sensitivity to moisture and need to be plasticized. Moreover, without modification, films made from whey proteins show relatively poor mechanical performance compared to synthetic films (Pérez-Gago et al., 1999; Kokoszka et al., 2010).

To address these drawbacks, the application of nanocomposites, which has proved to be a suitable strategy to overcome drawbacks derived from the neat polymeric matrix in the area of synthetic polymers in recent years (Giannelis, 1996; Sinha Ray and Okamoto, 2003; Kim et al., 2010; Huang et al., 2015), has led to considerable interest in nanocomposites based on biopolymer matrices (Alexandre and Dubois, 2000; Sorrentino et al., 2007; Paul and Robeson, 2008; Mittal, 2009). Based on the nanometersize of these particles, their application in biopolymers can lead to significant property enhancements, such as mechanical and barrier properties, when compared to conventional (macroscale) composites (Alexandre and Dubois, 2000; Sorrentino et al., 2007). With regard to the mechanical properties of nanocomposites, considerable attention has been paid to unexpected large increases in material stiffness [Young's modulus (YM)] as well as other mechanical characteristics which occur starting at relatively low filler loadings (<1\% w/w) (Sinha Ray and Okamoto, 2003; Almasi et al., 2010; Zolfi et al., 2014). In addition, nanocomposites have been studied for their ability to retard gas and water vapor transmission by extending the pathway and time for diffusing molecules, making it more tortuous (Bharadwaj, 2001; Bharadwaj et al., 2002). Another advantage of nano-sized particles is that these fillers, in contrast to micro- or macro-composites, do not affect the transparency of the composite matrix as their dimensions are smaller than the wavelengths of visual light (Yang et al., 1999; Alexandre and Dubois, 2000; Zeng et al., 2005). To take full advantage of the enhancements enabled by the nanometer size of the particles, uniform and nanoscale dispersion of the particles in the continuous polymer matrix is an essential step in the formation of nanocomposites (Yang et al., 1999). In the case of layered silicates, depending on the nature and type of the matrix, compatibility between matrix and filler, as well as the mixing process, different composite structures can be obtained (Paul and Robeson, 2008). True nanocomposites comprise intercalated or exfoliated structures. An intercalated structure arises when a certain number of extended polymer chains diffuse in between the layered silicates, resulting in well-ordered multilayer structures with alternating polymeric and inorganic layers and increased interlayer spacing. In this case, the layered silicates remain parallel to each other, even though the spacing between them increases. An exfoliated (or delaminated) structure is represented (ideally) by uniformly dispersed silicate monolayers. By contrast, when the polymer is not able to intercalate between the layered silicates, a phase separated (micro-)composite is obtained with properties in the same range of traditional microcomposites (Alexandre and Dubois, 2000; Sorrentino et al., 2007; Paul and Robeson, 2008; Mittal, 2009). Among the most commonly used layered silicates is natural montmorillonite (MMT) nanoplatelets (Alexandre and Dubois, 2000; Dean et al., 2007; Almasi et al., 2010), as they are commercially available at relatively low cost, environmentally friendly, and approved for food packaging applications (Sorrentino et al., 2007). They are plate-like nanoparticles with physical dimensions of about $100 \mathrm{~nm}$ in diameter and $1 \mathrm{~nm}$ in thickness (Paul and Robeson, 2008; Mittal, 2009). In addition, owing to their partially polar surfaces, MMT nanoplatelets display good compatibility with polar polymer matrices in general and whey proteins in particular (Müller et al., 2017), which leads to extensive interfacial interactions between the filler and the matrix via hydrogen bonding (Almasi et al., 2010). As a result, a higher degree of filler exfoliation is more likely to be achieved, which likewise leads to larger interfacial regions between the matrix and the nanofiller (Arora and Padua, 2010).

Hence, among other biopolymers (Park et al., 2002; Petersson and Oksman, 2006; Almasi et al., 2010), whey protein-based nanocomposites have become a promising field of interest in recent years (Hedenqvist et al., 2006; Zhou et al., 2009; Sothornvit et al., 2010; Li et al., 2011; Kadam et al., 2013; Zolfi et al., 2014; Azevedo et al., 2015; Wakai and Almenar, 2015; Hassannia-Kolaee et al., 2016a,b; Oymaci and Altinkaya, 2016). Previous research on whey protein isolate (WPI) nanocomposites demonstrated that the barrier and mechanical properties of these materials improved with increasing nanofiller loadings (Sothornvit et al., 2010; Zolfi et al., 2014; Azevedo et al., 2015; Hassannia-Kolaee et al., 2016a; Oymaci and Altinkaya, 2016; Zink et al., 2016). However, the addition of the nanofillers also caused considerably increased viscosities of the respective nanodispersions, which led to limitations in film processing due to insufficient mixing, foaming, and enclosed air. WPI-based nanodispersions from native whey proteins show lower initial viscosities as no heat-induced thermal crosslinking has taken place (McClements and Keogh, 1995). To obtain desirable properties, such as mechanical strength and ductility, thermal denaturation is an essential step in the formation of whey protein-based films (Pérez-Gago et al., 1999) and takes place after the nanofillers are added and the films or coatings are applied during the drying and curing process as invented previously by the authors in patent by Schmid et al. (2013).

The main goal of this study was the development of exfoliated WPI-based MMT nanocomposites from initially native WPIbased nanodispersions to further enhance barrier and mechanical properties and thus increase material suitability for industrial packaging applications. The related scientific issues were to investigate the effects of the addition of MMT nanoplatelets on whey protein-based nanocomposite films and coatings. In this context, also the influence of the protein concentration and the type of plasticizer on the processability and food packaging-related technofunctional properties of WPI-based nanocomposite cast films and coatings with emphasis on packaging-related properties were examined.

\section{MATERIALS AND METHODS}

\section{Materials}

Whey protein isolate was obtained from Davisco Foods International Inc., Le Sueur, MN, USA. The aqueous MMT-based 
nanodispersions were provided by ITENE, Valencia, Spain. The aqueous nanodispersions both consisted of 5\% (w/w) MMT, but differed in their plasticizer and water content. The glycerol-plasticized nanodispersions product no. is ITENE0006, whereas the sorbitol-plasticized nanodispersions product no. is ITENE0004. Plasticizers used for the final film-forming dispersions were glycerol (Merck KGaA, Darmstadt, Germany) and sorbitol (Th. Geyer GmbH \& Co. KG, Renningen, Germany). Coatings were applied on a chemically treated, $23 \mu \mathrm{m}$ polyethylene terephthalate (PET) film (Sarafil Polyplex Polyester Film, Polyplex, Thailand).

\section{Preparation of WPI-Based Film-Forming Nanodispersions}

To produce native WPI-based nanosuspensions, at first the MMT-based nanodispersions need to be exposed to high shearforces to obtain homogenously distributed nanodispersions and to exfoliate nanoclusters. Exfoliation of MMT nanoplatelets is necessary as these clays are clustered into platelets with low surface area (Sinha Ray and Okamoto, 2003; McAdam et al., 2008). Thus, MMT nanodispersions were mixed in a heatable electric stirrer (Thermomix TM 31-1, Vorwerk GmbH \& Co. $\mathrm{KG}$, Wuppertal, Germany) at $2,000 \mathrm{rpm}$ and $23^{\circ} \mathrm{C}$ for $30 \mathrm{~min}$. To prepare the film-forming nanodispersions, at first the desired amount of nanodispersion was mixed at $200 \mathrm{rpm}$ and $23^{\circ} \mathrm{C}$ for $30 \mathrm{~min}$ with the necessary amount of deionized water required for the protein standard solution using an magnetic stirrer (Ikamag RCT, IKA-Labortechnik, Staufen, Germany). The amount of nanodispersions added was determined in respect to obtain the desired amount [0\% (reference), 3, 6, $9 \%$ (w/w protein) MMT, or, depending on the protein concentration, also 12 and $15 \%(\mathrm{w} / \mathrm{w}$ protein) MMT] of nanofiller in the final film-forming dispersion. The highest possible concentration of the nanodispersions is dependent on the concentration of the native protein. WPI-based MMT nanodispersions were mixed into whey protein standard solutions containing $10 \%$ (w/w dispersion) or $15 \%$ (w/w dispersion) WPI. Preliminary tests showed possible concentrations of MMT of up to $15 \%$ (w/w protein) in case of a protein concentration of $10 \%$ (w/w dispersion) and up to $9 \%$ (w/w protein) in case of a protein concentration of $15 \%$ (w/w dispersion). After complete dispersal, depending on the desired plasticizer type and protein concentration, $100.00 \%$ (w/w protein) glycerol or sorbitol were added into the mixture and stirred at $200 \mathrm{rpm}$ and $23^{\circ} \mathrm{C}$ for $30 \mathrm{~min}$. Hereby, due to the higher protein content, dispersions with 15\% (w/w dispersion) WPI were plasticized with $100.00 \%$ (w/w protein) plasticizer. Subsequently, the desired amount of WPI, being either $10 \%$ (w/w dispersion) or $15 \%$ (w/w dispersion), were carefully mixed into the dispersion, successively, and stirred for $30 \mathrm{~min}$ at $23^{\circ} \mathrm{C}$ and $200 \mathrm{rpm}$. To remove air incorporated during mixing, all nanosuspensions were degassed in an ultrasonic bath (DT 514H, Bandelin electronic GmbH \& Co KG, Berlin, Germany) for $30 \mathrm{~min}$ at $23^{\circ} \mathrm{C}$ and $35 \mathrm{kHz}$.

\section{Preparation of WPI-Based Nanocomposite Cast Films and Coatings}

All film-forming nanodispersions were coated on a chemically treated, $23 \mu \mathrm{m}$ PET film (Sarafil Polyplex Polyester Film,
Polyplex, Thailand). Coatings were applied using the coating Unit CUF 5 (Sumet Messtechnik, Denklingen, Germany) with an actuation speed of $40 \mathrm{~mm} \mathrm{~s}^{-1}$ and a contact pressure of $40 \mathrm{~N}$. Denaturation of the native WPI was achieved during the drying process which took place directly after application of the wet film. Drying of the applied coatings was conducted at a drying temperature of $105^{\circ} \mathrm{C}$ in a build-in convective dryer and an infrared radiation intensity of $100 \%$. The drying interval varied between 4 and $12 \mathrm{~min}$ in respect to the dry matter content of the respective film formulation. To obtain a target dry film thickness of $13 \mu \mathrm{m}$, different wired rods in respect to the dry matter content of the individual film formulations were used. Coatings with a protein content of $10 \%$ (w/w dispersion) WPI were applied with the aid of a $75-\mu \mathrm{m}$ wired rod whereas for coatings with a protein content of $15 \%$ (w/w dispersion) a $55-\mu \mathrm{m}$ wired rod was used. After drying, the coated PET sheets were stored at ambient conditions of $23^{\circ} \mathrm{C}$ and $50 \%$ r.h. for 14-21 days until they reached moisture equilibrium. Cast films of WPI-based MMT nanocomposites were manufactured by solvent casting method from their aqueous solution. Films with target thicknesses of $200 \pm 20 \mu \mathrm{m}$ were casted in Petri dishes and denatured in a convective oven (HerathermOMH100, Thermo Fischer Scientific, Langenselbold, Germany) at $90^{\circ} \mathrm{C}$ for $40 \mathrm{~min}$. The denatured films were stored at $23^{\circ} \mathrm{C}$ and $50 \%$ r.h. for $14-21$ days until they reached moisture equilibrium.

\section{Viscosity Measurements}

Viscosity measurements were performed using a rotational rheometer Bohlin CV100 (Bohlin Instruments Ltd., Cirencester, UK). Viscosity measurements were carried out in a coaxialcylinder measuring configuration with a cone-geometry for the inner cylinder. A shear-rate ramp from 1 to $300 \mathrm{~s}^{-1}$ at $23^{\circ} \mathrm{C}$ was applied for $210 \mathrm{~s}$.

\section{Barrier Properties Oxygen Permeability}

The OP was measured with the oxygen-specific carrier gas method according to DIN 53380-3. The measurements were performed with an Ox-Tran Twin Oxygen-Permeation Measuring Machine (Mocon Inc., Minneapolis, MN, USA) at a temperature of $23^{\circ} \mathrm{C}$ and $50 \%$ r.h. The measurement stopped when a value was constant for at least $10 \mathrm{~h}$. A twofold determination for all coatings and cast film specimens was carried out. The OP is given in the unit $\mathrm{cm}^{3}$ (STP) $\mathrm{m}^{-2}$ day $^{-1}$ bar $^{-1}$ (DIN, 1998).

\section{Water Vapor Transmission Rate (WVTR)}

The WVTR was measured by the gravimetric screw-cup method according to the standard DIN 53122-1. According to DIN 53122-1, the film samples were fixed on a glass or metal cup containing dried silica-gel, which generates an atmosphere of $1.3 \%$ r.h. (referred to $0 \%$ r.h.) and was sealed with vacuum grease and screws to avoid leaks. The samples were weighted and placed in a climate controlled cabinet $\left(23^{\circ} \mathrm{C} / 50 \%\right.$ r.h. $)$. This generates a relative humidity gradient of $50 \% \rightarrow 0 \%$ r.h. The cups were reweighted periodically. The gained weight indicates the amount of permeating water vapor. A fourfold determination was carried out unless indicated otherwise. Arithmetic mean and SDs 
were calculated. The WVTR is the change in weight of the whole cup and can be calculated using Eq. 1, whereby $t$ is the period of time between two weight measurements [h], $\Delta m$ is the weight difference between two weight measurements [g], $A$ is the test area $\left[\mathrm{cm}^{2}\right]$, and WVTR is the water vapor transmission rate [ $\mathrm{g} \mathrm{m}^{-2}$ day $^{-1}$ ] (DIN, 2001; Robertson, 2006):

$$
\mathrm{WVTR}=\frac{24}{t} * \frac{\Delta m}{A} * 10^{4} \quad\left[\mathrm{~g} \mathrm{~m}^{-2} \mathrm{day}^{-1}\right] .
$$

The permeability, $Q$, of a polymer can be calculated using Eq. 2 as the quotient of the permeation coefficient, $P$, and the thickness, $d$, of a polymer (Langowski, 2008):

$$
Q=\frac{P}{d} \quad\left[\mathrm{~cm}^{3}(\mathrm{STP}) \mathrm{m}^{-2} \mathrm{day}^{-1} \mathrm{bar}^{-1}\right] .
$$

To adapt permeability properties of a packaging material, multilayers can be used instead of raising the thickness of a monolayer. The total permeability of a multilayer structure, $Q_{\text {total }}$, can be calculated using Eq. 3, whereby $d_{i}$ represents the thickness of the individual layers $\left(d_{i}, d=\sum d_{i}\right)$, and $P_{i}$ represents the permeation coefficient of the individual layers $\left(P_{i}, P=\sum P_{i}\right)$. Alternatively, the total permeability of a multilayer structure can be calculated from the respective permeabilities of the individual layers, $Q_{n}$, whereby the superscripts ( 1 and 2 ) represent the respective layers (Schmid et al., 2012):

$$
\frac{1}{Q_{\text {total }}}=\sum_{i=1}^{i=n} \frac{d_{i}}{P_{i}}=\frac{1}{Q_{1}}+\frac{1}{Q_{2}}+\ldots \frac{1}{Q n} .
$$

For a better comparability between different specimens independently of the respective layer thicknesses, the permeability, $Q$, can be standardized to the $Q_{100}$-value relating to a thickness, $d$, of $100 \mu \mathrm{m}$ (Menges, 2002):

$$
Q_{100}=Q * \frac{d}{100} .
$$

\section{Determination of the Thickness}

Thickness measurements were carried out according to DIN 53 370. The thickness was measured using a Precision Thickness Gauge FT3 (Rhopoint Instruments Ltd., Beyhill-on-Sea, UK) by measuring five film-specimen each at five random positions and averaging the results. For barrier and mechanical properties, individual thicknesses of each specimen were measured at $23^{\circ} \mathrm{C}$ and $50 \%$ r.h.

\section{Mechanical Measurements}

The mechanical properties of the cast films were analyzed by using the tensile testing machine Z005 (Zwick GmbH \& Co. KG, Ulm, Germany) at $23^{\circ} \mathrm{C}$ and $50 \%$ r.h. The tensile strength (TS), $\mathrm{YM}$, and elongation at break (E\%) were determined according to the test standards of DIN EN ISO 527-1. Tests were performed with sample strips of $15 \mathrm{~mm}$ width and an initial clamping length of $50 \mathrm{~mm}$, using pneumatic grips to fix the samples in the loading frame. The samples were stretched applying a test-speed of $200 \mathrm{~mm} \mathrm{~min}^{-1}$ with a load shut-off at $95 \%$ and a preload of $0.3 \mathrm{~N}$. For Young's modulus measurement a test-speed of $0.5 \mathrm{~mm} \mathrm{~min}^{-1}$ was used. For all tested samples, at least a fivefold determination was performed (DIN, 2012).

\section{Determination of the Surface Free Energy (SFE)}

The surface energy of WPI-based nanocomposite cast films was measured by the Drop Shape Analyser-DSA100 (Krüss GmbH, Stephanskirchen/Rosenheim, Germany), using the sessile drop method. To determine the SFE of a solid material, one has to determine the contact angle between the baseline of an applied liquid droplet and the tangent at the drop boundary. Therefore, the samples are positioned on a moveable suction plate, which is connected to a vacuum pump, and fixed using tape. Subsequently, a volume of approximately $3 \mu \mathrm{l}$ of three different test-liquids with well-known surface tension is applied on the surface of the samples $(7.5 \mathrm{~mm} \times 7.5 \mathrm{~mm})$ using an automatic glass-syringe with a dosing rate of $20 \mu \mathrm{m} \mathrm{min}^{-1}$ to apply an ideal droplet. After an ideal liquid droplet was set, the screen was frozen after $20 \mathrm{~s}$ to determine the contact angle between the baseline of the solid material and the tangent at the drop boundary of the test liquids. The used test liquids were double distilled water $\left(\mathrm{H}_{2} \mathrm{O}\right)$, diiodomethane $\left(\mathrm{CH}_{2} \mathrm{I}_{2}\right)$, and ethylene-glycol $\left(\mathrm{C}_{2} \mathrm{H}_{6} \mathrm{O}_{2}\right)$. The contact angle of each test liquid was determined at five different positions on the surface of five specimens. Arithmetic mean values were calculated for each sample set. The SFE of the solid material can now be calculated using the Young's Eq. 5, where $\sigma_{s}$ is the surface tension of the solid material $\left[\mathrm{mN} \mathrm{m}^{-1}\right], \sigma_{l}$ is the surface tension of the test liquids $\left[\mathrm{mN} \mathrm{m}^{-1}\right], \gamma_{s l}$ is the interfacial tension between the solid and the liquid $\left[\mathrm{mN} \mathrm{m}^{-1}\right]$, and $\cos \theta$ is the contact angle between the surface tension of the test liquid and the interfacial tension between the test liquid and the solid in angular degree:

$$
\sigma_{s}=\gamma_{s l}+\sigma_{l} * \cos \theta \quad\left[\mathrm{mNm}^{-1}\right] .
$$

According to the Owens, Wendt, Rabel, and Kaelble method, the SFE can be split into a dispersive and a polar part. Consequently, the SFE of the tested cast film samples was split into their polar and dispersive part to determine the character of the surface. As the tested cast films are still partly soluble, the contact angle was determined after a certain amount of time $(20 \mathrm{~s})$ instead of the equilibrium as it is highly time dependent. Therefore, contact angles and surface free energies are not absolute values but, however, they are suitable to draw conclusion on the character of the film surface and to compare the samples (Schmid, 2013).

\section{Optical Measurements}

The color measurements (CIE-Lab) of WPI-based nanocomposites were performed using the spectrophotometer CM-700d (Konica Minolta, Inc., Tokyo, Japan) with SAV aperture $(\Phi 3 / \Phi 6 \mathrm{~mm})$. An illuminant D65 and a wavelength range starting from 400 to $700 \mathrm{~nm}$ were used. Calibration of the spectrophotometer was conducted using a white and black ceramic plate calibration-standard following the Konica Minolta calibration procedure. However, the samples were too sticky to use the white ceramic plate as reference sample thus, a white paper was used. For each sample, a threefold determination was performed. Average $L^{*}-, a^{*}$-, and $b^{*}$-values and SDs were calculated. 


\section{Statistical Analysis}

The results were analyzed using the statistical software Visual XSel 12.0 (CRGRAPH GbR, Starnberg, Germany). Measured data from mechanical and WVTR determination were tested for normal distribution using either Kolmogorov-Smirnov test (sample size $\leq 4$ ) or Anderson-Darling normality test (sample size $\geq 5$ ) both with a level of significance $\alpha=0.05$. Outliers were detected and eliminated with the outlier test according to Hampel ( $\alpha=0.05)$. Multiple $t$-tests were performed to determine whether there were significant differences $(p \leq 0.05)$ between the measured values.

\section{RESULTS AND DISCUSSION}

Table 1 illustrates which measurements were performed on which cast films and coatings.

\section{Viscosity Measurement}

Figures 1 and $\mathbf{2}$ illustrate the rheological-flow behavior of native WPI-based film-forming dispersions and their nanocomposites. The addition of MMT nanoparticles generally led to considerably increased dynamic viscosities of the tested nanocomposite dispersions. This effect became especially pronounced with higher nanofiller loadings beginning at filler loadings of $9 \%(\mathrm{w} / \mathrm{w}$ protein) for film-forming nanocomposite dispersions with a

TABLE 1 | Implemented measurements for whey protein isolate (WPI)-based montmorillonite nanocomposite cast films and coatings.

\begin{tabular}{lcccccc}
\hline \multirow{2}{*}{$\begin{array}{l}\text { Implemented } \\
\text { measurements }\end{array}$} & \multicolumn{2}{c}{ Coatings } & & \multicolumn{2}{c}{ Cast films } \\
\cline { 2 - 3 } \cline { 5 - 6 } & Glycerol & Sorbitol & & Glycerol & Sorbitol \\
\hline Wetting properties & - & - & & $x$ & $x$ \\
Optical properties & - & - & & $x$ & $x$ \\
Mechanical properties & - & - & & $x$ & - \\
Oxygen permeability & $x$ & & $x$ & & Only $10 \%$ & Only 10\% \\
Water vapor transmission rate & - & - & & - & (w/w) WPI & (w/w) WPI
\end{tabular}

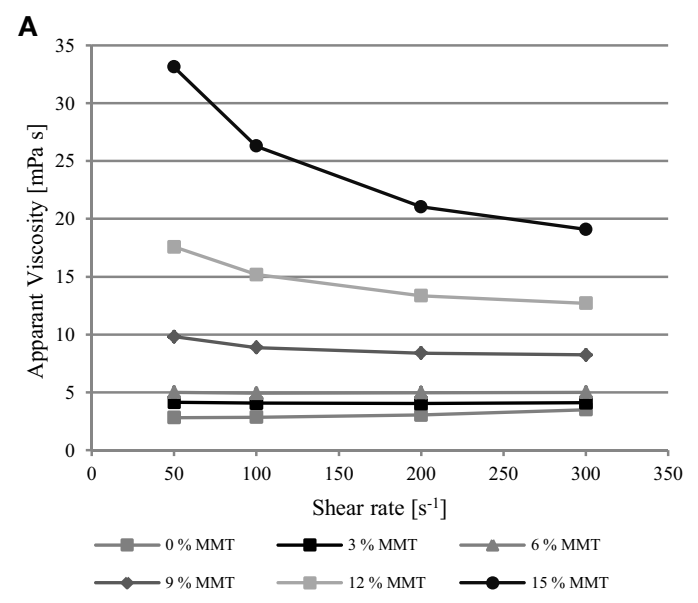

WPI content of $10 \%(\mathrm{w} / \mathrm{w})$ and for filler loadings beginning at $6 \%(\mathrm{w} / \mathrm{w}$ protein) in case of a WPI content of $15 \%(\mathrm{w} / \mathrm{w})$. It is well known that the viscosity of filled polymers, considerably at low shear-rates, increases and, for a certain shear-rate, continues to do so with increasing nanofiller loading (Binder et al., 2003). These changes of apparent viscosity of filled polymers are caused by the particulate matter input and thus increased solid volume-fraction (Geraldo De et al., 2009). It was therefore only possible to include up to $9 \%(\mathrm{w} / \mathrm{w})$ MMT into $15 \%(\mathrm{w} / \mathrm{w})$ WPI nanocomposites films. Higher nanofiller loadings led to extensive foaming during processing, a lack of fluidity during pouring of the cast films, and entrapped air bubbles. Moreover, it can be observed from the rheograms that with rising MMT loading the nanocomposites progressively became more and more shear-thinning upon an increasing shear-rate. In case of glycerol-plasticized $10 \%(\mathrm{w} / \mathrm{w})$ WPI-based nanodispersions, a shear-thinning flow behavior with rising shear-rates could already be observed starting from 9\% MMT loading, although the effect became clearer with higher particle loadings. Below this critical MMT loading, regardless of the presence of the nanofiller, nanodispersions behaved nearly ideal-viscous following a Newtonian flow behavior. Similar results were obtained for sorbitol-plasticized $10 \%$ (w/w) nanodispersions. The development of a shear-thinning flow behavior with increasing shear-rate can be attributed to the reorientation of the MMT platelets toward the direction of flow while shearing forces are applied to the nanodispersions and to interactions between the surface of the MMT platelets and the hydrophilic protein-plasticizer phase (Echeverría et al., 2014). As the reorientation of the nanofiller takes places, the viscosities of such nanodispersions approach the initial viscosity of the pure polymer with rising shear-rate (Mittal, 2012). This phenomenon has been reported by several other studies for synthetic polymers (Giannelis, 1996; Manias et al., 1996; Krishnamoorti et al., 2001) and for biopolymers (Tunc et al., 2007; Echeverría et al., 2014).

Similar results were obtained when the WPI content of nanocomposite dispersions rose to 15\% (w/w) (Figure 2). The apparent viscosity generally rose due to the higher solids content

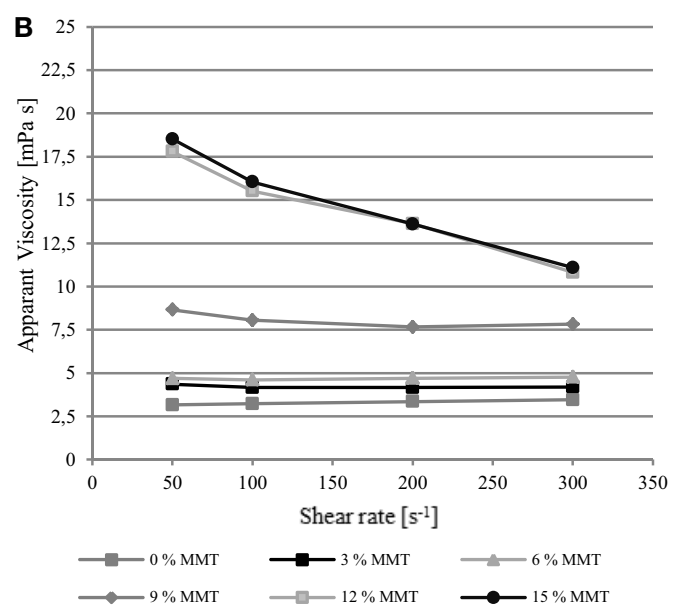

FIGURE 1 | Apparent viscosity dependent on the shear rate from 50 to 300 [ $\mathbf{S}^{-1}$ of native whey protein isolate (WPI)-based nanocomposite dispersions with $10 \%$ (w/w) WPI, 66.70\% (w/w protein), and an increasing montmorillonite (MMT) nanofiller loading, plasticized with (A) glycerol or (B) sorbitol. 

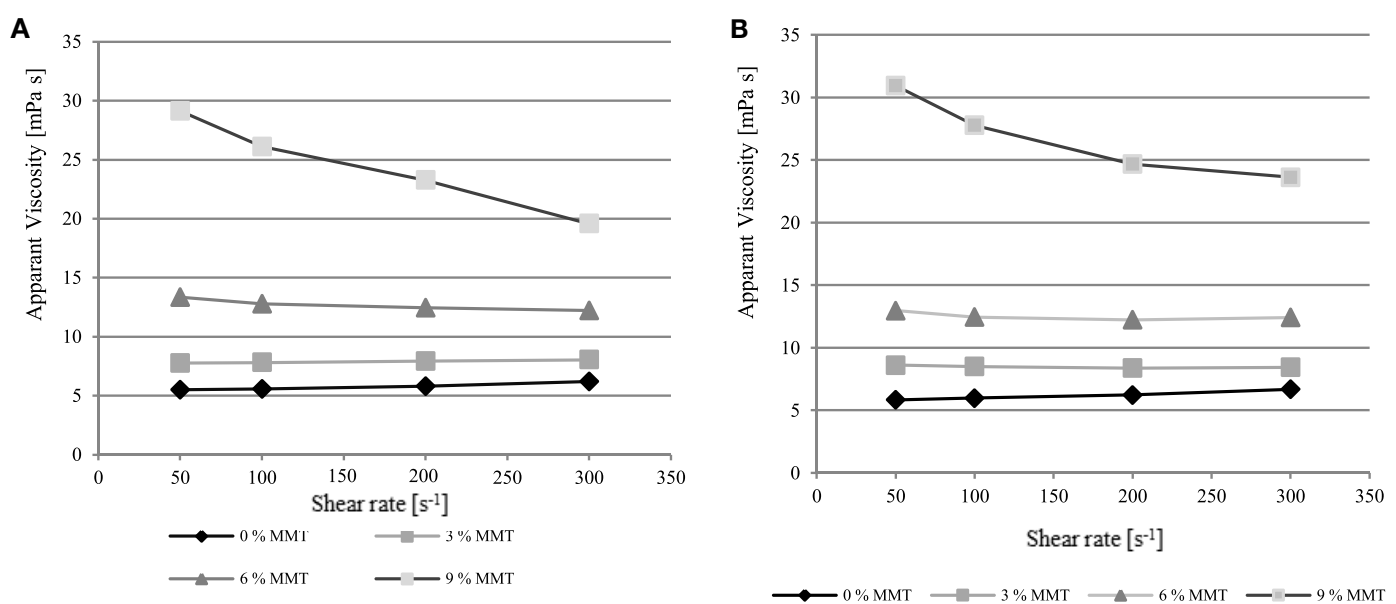

FIGURE 2 | Apparent viscosity dependent on the shear rate from 50 to $300\left[\mathrm{~s}^{-1}\right]$ of native whey protein isolate (WPI)-based nanocomposite dispersions with 15\% (w/w) WPI, 66.70\% (w/w protein), and an increasing montmorillonite (MMT) nanofiller loading, plasticized with (A) glycerol or (B) sorbitol.

(Matijašić and Glasnović, 2002). Again, it can be observed that regardless of the plasticizer type, nanodispersions progressively became more and more shear thinning upon an increasing shear-rate, starting from a MMT loading of $9 \%$ (w/w protein), while WPI-nanocomposite dispersions below this critical concentration behaved nearly ideal viscous. The addition of MMT nanoplatelets, except the sorbitol-plasticized nanocomposite dispersion with 10\% (w/w) WPI and 15\% MMT loading (w/w protein), always led an increase of the apparent viscosities of the tested nanocomposites. In comparison, when glycerol was used as a plasticizer, the increase in MMT loading from 9 to $15 \%$ (w/w protein) led to considerable changes in apparent viscosity. This effect, in particular, may be attributed to the processing conditions of the film-forming dispersions, but cannot be clarified from the available data. Apart from that, no considerable differences regarding the plasticizer type were identified. Thus, we assume that the plasticizer type does not have significant influence on the apparent viscosity of native WPI-based nanocomposite dispersions. The apparent viscosity of all tested nanodispersions lies between 5 and $30 \mathrm{mPa} \mathrm{s}^{-1}$ at a shear-rate of $D=100 \mathrm{~s}^{-1}$ which demonstrates that the viscosity of native WPI-based nanocomposite dispersions, compared to already denatured dispersions, could be considerably enhanced.

\section{Barrier Properties Oxygen Permeability}

Oxygen permeability measurements were performed for cast films and coatings (Table 1). For better compatibility, only the permeability of the coating (monolayer) is considered as the OP of PET is much higher. Permeability of the coating monolayer can be calculated according to Eq. 3. The measurements were normalized to a layer thickness of $100 \mu \mathrm{m}\left(Q_{100}\right)$ using Eq. 2. The following figures demonstrate the $Q_{100}$ values of the cast films and coatings with a protein content of 10 and $15 \%$ protein (w/w) and either $66.70 \%$ glycerol/sorbitol or $100.00 \%$ glycerol/sorbitol (w/w) as plasticizer. The percentages of MMT always refer to the weight of the protein. Figure 3 and Table 2 show the OP of WPI-based nanocomposite cast films and coatings. OP measurements were performed according to DIN $53380-3$ at $23^{\circ} \mathrm{C}$ and $50 \%$ r.h.

The results show that the addition of MMT nanoplatelets led to a continuously decreasing $\mathrm{OP}$ of the coatings monolayer. In comparison to the reference, the addition of $3 \% \mathrm{MMT}$ (w/w protein) into glycerol-plasticized coatings already improved the oxygen repellency by a factor about 2 . The lowest OP, as expected, could be observed for coatings with the highest nanofiller loadings, representing a reduction of the $\mathrm{OP}$ compared to the reference (without nanofiller) by a factor about 10. For sorbitol-plasticized nanocomposite coatings, with exception of coatings with $9 \%$ (w/w protein) nanofillers, the OP also decreased but, however, the effect of the increasing nanofiller loading toward the OP was not as clear as for glycerol-plasticized coatings. The renewed increase in OP at $9 \%$ (w/w protein) nanofillers could be explained by the orientation of the nanoplatelets within the protein network as with further addition of nanofillers the OP started to decline again until it reached its least permeability of approximately $0.58 \mathrm{~cm}^{3} \mathrm{~m}^{-2}$ $\mathrm{day}^{-1} \mathrm{bar}^{-1}$ at the highest filler loading which is in the range of the permeability values of EVOH (Schmid et al., 2012). These results underline that WPI-based nanocomposite coatings are capable of replacing commercial petroleum-based barrier polymers, e.g., ethylene-vinyl alcohol copolymer (EVOH 44\%) which is used in multilayer flexible packaging applications as an effective barrier against gases and particularly against oxygen permeation. An improvement of the OP with increasing nanofiller-content was also observed by Oguzlu and Tihminlioglu (2010) for chitosanbased nanocomposite films. Decreases in OP could be attributed to the presence of the dispersed nanoplatelets which, depending on their alignment and state of exfoliation, exhibit very large aspect ratios. This consequently led to increased tortuosity and longer pathways for permeating gas molecules (Ray et al., 2006; Yoo et al., 2014; Visakh and Sigrid, 2016). However, based on a more uniform dispersion at low filler loadings and thus better exfoliation of nanoparticles, other researchers reported lower OP with decreasing nanofiller content (Weizman et al., 2017). For coatings with $15 \%(\mathrm{w} / \mathrm{w})$ WPI and $100.00 \%$ (w/w protein) 


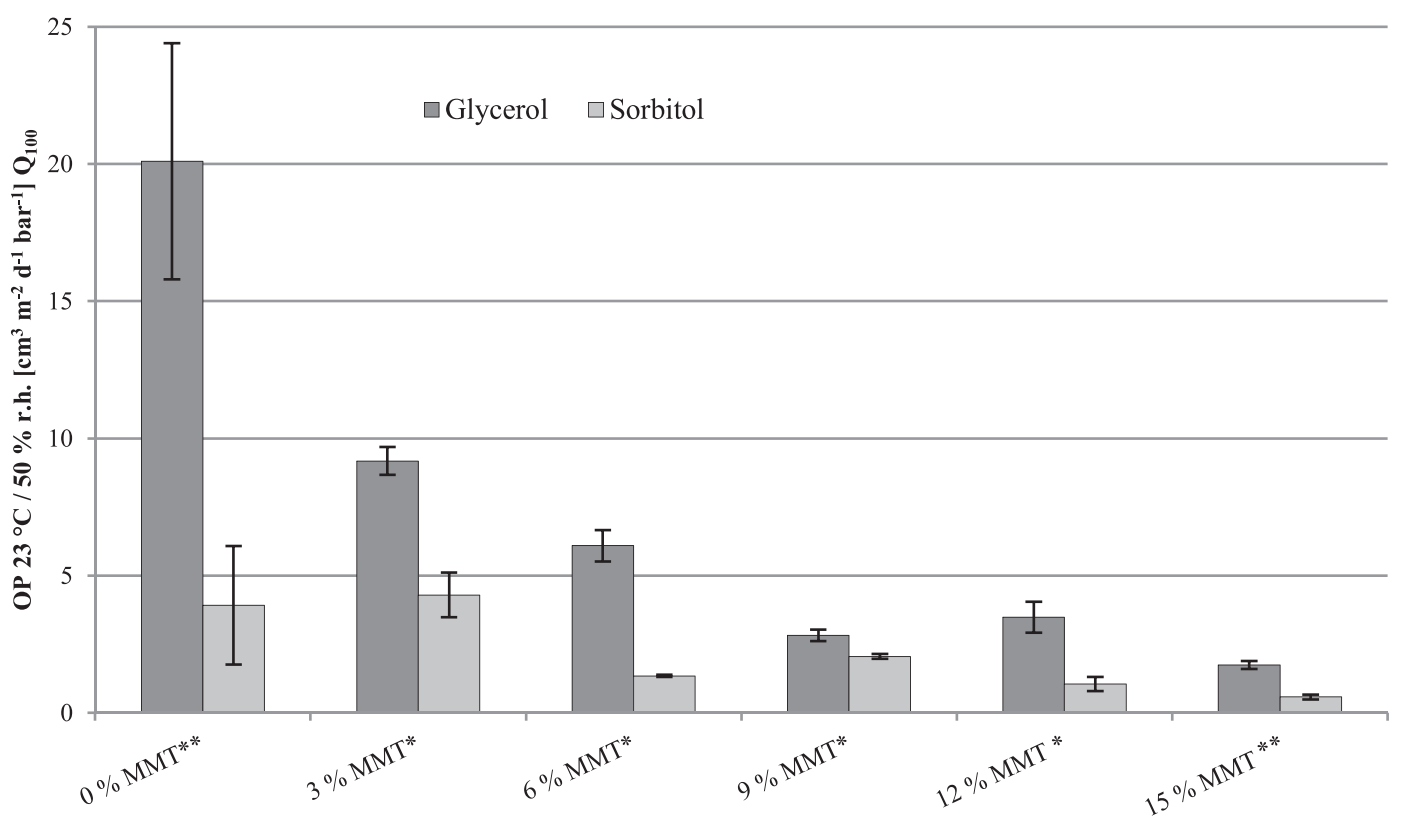

FIGURE 3 | Effect of different montmorillonite (MMT) nanofiller loadings on oxygen permeability ( $\left.Q_{100}\right)$ of whey protein isolate-based (10\% w/w) nanocomposite coatings with $66.70 \%$ (w/w protein) glycerol or sorbitol. *Error bars show minimum and maximum values of a twofold determination. **Error bars show SDs of a threefold determination.

TABLE 2 | Effects of different montmorillonite (MMT) nanofiller-loadings on oxygen permeability $\left(Q_{100}\right)$ of whey protein isolate $(\mathrm{WPI})$-based nanocomposite cast films and coatings.

\begin{tabular}{|c|c|c|c|c|}
\hline \multirow{3}{*}{$\begin{array}{l}\text { MMT-(w/w } \\
\text { protein) }\end{array}$} & \multicolumn{4}{|c|}{ OP $23^{\circ} \mathrm{C} / 50 \%$ r.h. $\left(\mathrm{cm}^{3} \mathrm{~m}^{-2}\right.$ day $^{-1}$ bar $\left.^{-1}\right) Q_{100}$} \\
\hline & \multicolumn{2}{|c|}{$\begin{array}{c}\text { Cast films } 10 \%(w / w) \\
\text { WPI, } 66.70 \%(w / w \text { protein) } \\
\text { plasticizer }\end{array}$} & \multicolumn{2}{|c|}{$\begin{array}{c}\text { Coatings } 15 \%(w / w) \text { WPI, } \\
100.00 \% \text { (w/w protein) } \\
\text { plasticizer }\end{array}$} \\
\hline & Glycerol & Sorbitol & Glycerol & Sorbitol \\
\hline 0 & $93.59 \pm 11.54^{b}$ & $1.43 \pm 0.23^{b}$ & $45.13 \pm 17.82$ & $3.15 \pm 0.87$ \\
\hline 3 & $60.80 \pm 1.43^{b}$ & $1.99 \pm 0.78^{b}$ & $12.98 \pm 1.15$ & $0.92 \pm 0.07$ \\
\hline 6 & $59.21 \pm 1.11^{b}$ & $0.74 \pm 0.38^{b}$ & $6.96 \pm 0.27$ & $1.33 \pm 0.08$ \\
\hline 9 & $45.68 \pm 0.21^{b}$ & $0.56^{a}$ & $4.91 \pm 0.77$ & $0.91 \pm 0.13$ \\
\hline 12 & $29.61 \pm 1.75^{b}$ & $2.52 \pm 1.06^{b}$ & - & - \\
\hline 15 & $11.29 \pm 9.17^{\circ}$ & $2.31^{a}$ & - & - \\
\hline
\end{tabular}

asingle value.

${ }^{b}$ Minimum and maximum values of a twofold determination.

'SDs of a threefold determination.

plasticizer (Table 2), similar results as for the nanocomposite coatings with $10 \%(\mathrm{w} / \mathrm{w})$ WPI have been observed. The addition of $9 \%(w / w)$ MMT led to a reduction of the OP compared to the reference sample (without nanofiller) by about $90 \%$ in case of glycerol, and about $70 \%$ in case of sorbitol.

Similar observations were also made for the effect of different nanofiller loadings on the OP of nanocomposite cast films with $10 \%(\mathrm{w} / \mathrm{w}) \mathrm{WPI}$ and $66.70 \%$ (w/w protein) plasticizer (Table 2). In case of glycerol-plasticized nanocomposite cast films, an addition of $3 \%(\mathrm{w} / \mathrm{w}$ protein) MMT reduces the OP by about one third compared to the reference sample. Between 3 and $6 \%$ (w/w protein), nanofiller addition did not result in considerable differences regarding OP. However, further addition of nanofillers reduced the OP. At the highest filler content, the addition of MMT led to a reduction of the OP by a factor of about 8.45 compared to the reference sample. In case of the cast films with $15 \%$ (w/w protein) nanofillers and, especially for sorbitol-plasticized films, strong deviations in permeation data could be attributed to the orientation of the nanofillers in the WPI-matrix as an increased diffusion path, among other factors, is highly dependent on the lengthwise orientation of the nanofiller particles (Ray et al., 2006). To prove this hypothesis, the morphology of the cast films has to be examined by microscopy methods. Compared to the permeation data of the coatings, the cast films showed more deviations in OP. This can most likely be attributed to a more uniform application of the coating monolayer as the cast films showed large differences in their layer thicknesses due to uneven alignment during convection drying or the curing in a climate cabinet. Nevertheless, the reduction of the OP with increasing nanofiller content could be demonstrated.

As mentioned earlier for sorbitol-plasticized cast films and coatings, reduction of the OP was not as clear as for glycerolplasticized nanocomposite cast films. However, it should be noted that sorbitol was much more effective as cast films and coatings plasticized with sorbitol generally yielded much lower oxygen permeabilities compared to glycerol-plasticized cast films and coatings. Generally, protein-based films and coatings which are plasticized with sorbitol were reported to exhibit lower oxygen permeabilities than glycerol-plasticized films (McHugh and Krochta, 1994; Chick and Ustunol, 1998). Protein-based films in general are good barriers against the diffusion of small gas 
molecules like oxygen or carbon dioxide due to their hydrophilic nature (Miller and Krochta, 1997). However, the incorporation of plasticizers, e.g., polyols, increases the permeation coefficient (Lieberman and Gilbert, 1973; Schmid et al., 2012) due to increased absorption of moisture into the hydrophilic biopolymer network which consequently leads to increased intermolecular spacing as supported by free-volume theory (Lieberman and Gilbert, 1973). As glycerol, compared to sorbitol, shows a higher hygroscopicity (Shaw et al., 2002), its effectiveness in increasing the free-volume and thus increased permeation of oxygen molecules could be attributed to the structure of polyol plasticizers as glycerol is much smaller than sorbitol and thus, based on their molecular weight, more abundant at the same weight-\% bases. Counteracting to the contributions of the plasticizers in increasing the free-volume, however, extensive interfacial interactions between the hydrophilic polymer, plasticizer, and the MMT via hydrogen bonding could significantly lower the free-volume and thus lower the permeability (Huang et al., 2015).

\section{Water Vapor Transmission Rate}

The WVTR, as already mentioned earlier (see Table 1), was only determined for sorbitol-plasticized WPI-based nanocomposite cast films. Evaluation of glycerol-plasticized cast films with 10 and $15 \%$ protein $(\mathrm{w} / \mathrm{w})$ and $66.70 \%$ or $100.00 \%$ glycerol $(\mathrm{w} / \mathrm{w}$ protein), respectively, was not possible due to strong thickness fluctuations during the WVTR measurement. Therefore, it was not possible to obtain normalized transmission rates $\left(Q_{100^{-}}\right.$ values) for the different cast film formulations. This observation can most likely be attributed to the high-relative humidity gradient during the WVTR measurements ( 85 to $0 \%$ r.h.) which led to increased sorption of water molecules (Lieberman and Gilbert, 1973) into the hydrophilic protein matrix due to the highly hygroscopic properties of glycerol (Shaw et al., 2002). Table 3 shows the WVTRs $\left(Q_{100}\right)$ for sorbitol-plasticized cast films with 10 and $15 \%(\mathrm{w} / \mathrm{w})$ protein. All measured samples showed weak barrier properties against water vapor. The reference sample did not contain nanofillers and was measured to evaluate the effect of the nanofiller. It can be seen in Table 3 that with increasing nanofiller loading the WVTR for cast films containing $10 \%$ (w/w) WPI significantly $(p \leq 0.05)$ declines by

TABLE 3 | Water vapor transmission rate $\left(Q_{100}\right)$ of whey protein-based (10 and $15 \% \mathrm{w} / \mathrm{w}$ ) nanocomposite cast films with different concentrations of montmorillonite (MMT) nanofiller and $66.70 \%, 100 \%$ (w/w protein) sorbitol (Sor), respectively.

\begin{tabular}{|c|c|c|}
\hline \multirow{2}{*}{$\begin{array}{l}\text { MMT } \\
\text { (w/w protein) }\end{array}$} & \multicolumn{2}{|c|}{ WVTR $Q_{100}\left(\mathrm{~g} \mathrm{~m}^{-2}\right.$ day $\left.^{-1}\right)$} \\
\hline & $\begin{array}{c}\text { Sor, } 10 \%(w / w) \text { whey protein } \\
\text { isolate (WPI) }\end{array}$ & Sor, $15 \%$ (w/w) WPI \\
\hline 0 & $1,538.62 \pm 151.12^{a}$ & $1,267.76 \pm 166.50^{a}$ \\
\hline 3 & $1,302.33 \pm 112.11^{a b}$ & $1,322.96 \pm 286.70^{a}$ \\
\hline 6 & $1,170.79 \pm 35.20^{b}$ & $1,014.51 \pm 196.75^{\mathrm{ab}}$ \\
\hline 9 & $942.41 \pm 62.35^{\mathrm{c}}$ & $798.44 \pm 33.70^{\mathrm{b}}$ \\
\hline 12 & $633.95 \pm 82.08^{d}$ & - \\
\hline 15 & $641.70 \pm 16.22^{d}$ & - \\
\hline
\end{tabular}

Columns with different letters are significantly different $(p \leq 0.05)$ for each dataset. Measurement conditions were $23^{\circ} \mathrm{C}$ and $85 \% \rightarrow 0 \%$ r.h. Values represent mean $\pm S D$. about $60 \%$. The lowest transmission rates, as expected, were achieved for the highest nanofiller loadings [12 and 15\% (w/w, relative to protein) $\mathrm{MMT}$ ] even though these differences were not significantly different from each other. The addition of nanofillers reduces the WVTR because inorganic MMT nanoplatelets are impermeable to water molecules. Consequently, the water molecules must diffuse past these layers, which leads to an extension of the diffusion path (Giannelis, 1996).

Improved barrier properties against water vapor were also achieved for nanocomposite cast films containing 15\% (w/w) WPI (Table 3). Although the reduction of the WVTR is in part not significantly different, WVTR values could be significantly ( $p \leq 0.05$ ) reduced by approximately $37 \%$ for compositions containing the highest nanofiller loadings. With increasing MMT concentration this effect, however, reverses as the influence of an extended tortuous pathway for the diffusion of water molecules due to the impermeable nanoplatelets gains more influence which leads to a significant reduction of the WVTR as the water molecules must diffuse past the layered MMT (Giannelis, 1996; Bharadwaj, 2001; Bharadwaj et al., 2002). Another possible explanation for the reduced transmission of water molecules through the biopolymer matrix could be attributed to the ability of the WPI-matrix and the highly polar plasticizer molecules to build a more cohesive network with hydroxyl groups of the MMT via hydrogen bonding and thus lowering the absorption and diffusion of water molecules (Almasi et al., 2010). However, given the applied measuring conditions of 85 to $0 \%$ r.h. during WVTR measurements revealed that WPI-based nanocomposite cast films, regardless of the nanofiller-content, are still poor moisture barriers. This can clearly be attributed to the high relative humidity which most likely caused the hydrophilic protein matrix to swell. At high relative humidity water molecules accumulate between polar amino acid side chains consequently increasing the intermolecular spacing which results in an increased WVTR due to the increased free-volume between the polymer chains (Lieberman and Gilbert, 1973). This effect is further intensified by the presence of sorbitol as highly hygroscopic polyol plasticizers compete with water molecules for binding sites between polar amino acid sidechains (Lieberman and Gilbert, 1973). As a result, theoretical assumptions, e.g., constant diffusion and layer thicknesses, to calculate WVTR values are no longer valid which leads to inaccurate data (Oymaci and Altinkaya, 2016). However, when comparing the barrier improvements between WVTR and OP, it is apparent that generally much better barrier improvements were achieved in terms of OP compared to water vapor transmission even though the measurement conditions (high relative humidity, swollen biopolymer matrix) were the same. This observation is consistent with observations from Choi et al. (2006) using a non-swelling PET/clay-nanocomposite matrix. A possible explanation for the enhanced oxygen barrier properties could be referred to extensive interactions between the hydrophilic protein/plasticizer matrix, the permeating water molecules, and the hydrophilic surface of the nanofiller. Rhim et al. (2009) reported that the relative surface hydrophilicity of the used MMT nanoplatelets compared to other clays with relatively lower surface hydrophilicity was responsible for increased water vapor permeability's in a clay/PLA nanocomposite film. 
By taking into account the highly non-polar character of oxygen, this could be a suitable explanation for the clearly better barrier efficiency against the permeation of oxygen molecules than against water vapor.

\section{Mechanical Properties Effect of Nanofiller Concentration}

The effects of an increasing nanofiller concentration onto YM, elongation at break (E\%), and TS of WPI-based nanocomposite cast films are illustrated in Figures 4 and 5. Mechanical characteristics can be useful in identifying structural relationships of composite materials as they relate to their chemical structure (Ninnemann, 1968). The YM defines the relation between applied stress and the associated strain during the elastic deformation of a material. Thus, a high YM indicates high resistance against plastic deformation. The TS is the maximum tensile stress that a film can withstand without failure. Elongation at break (E\%) is defined as the ultimate relative length change a material can withstand before breaking and thus a measure for a materials ability to lengthen in relation to its original length. Mechanical measurements were performed at $23^{\circ} \mathrm{C}$ and $50 \%$ r.h. All films were prepared by solvent-casting method thus there is no specific testing direction. Due to extreme brittleness of sorbitol-plasticized nanocomposite cast films, only films containing glycerol as a plasticizer were used to evaluate the mechanical performance. The percentage of the nanofiller MMT refers to the weight of the protein in the film compositions.
For cast films with a protein content of $10 \%(\mathrm{w} / \mathrm{w}) \mathrm{WPI}$ and $66.70 \%$ (w/w protein) glycerol, it can be observed from Figure 4, that increasing the nanofiller, even at low filler loadings, has significant effects $(p \leq 0.05)$ on the mechanical properties. A significant improvement of the YM could already be observed between the reference sample and 3\% (w/w protein) MMT. The best results regarding the improvement of the YM were obtained at the highest nanofiller loadings (12 and 15\% w/w MMT). Although the differences between the highest nanofiller loadings (12 and 15\%) were not significantly $(p>0.05)$ different from each other, they were significantly different from the reference sample by about a factor of 4. Similar improvements were also achieved in the evaluation of the TS of these films. The addition of the nanofiller at its lowest concentration ( $3 \% \mathrm{w} / \mathrm{w}$ protein) led to improved TS values, even though these differences were not significantly $(p>0.05)$ different. However, further addition to a filler concentration of $6 \%(\mathrm{w} / \mathrm{w}$ protein) led to significant $(p \leq 0.05)$ changes in TS. Again, as for the YM measurement, it can be stated that the best results for the TS measurement could be achieved at the highest MMT concentrations. In case of elongation properties, in contrast to YM and TS, it can be observed from Figure 4 that the elongation at break $(\mathrm{E} \%)$ generally decreases with increasing nanofiller content, even though the reduction of film extensibility was not as clear as the changes in the other tensile properties (YM and TS). This can be attributed to strongly fluctuating film thicknesses which led to extensive standard variations for $\mathrm{E} \%$ as the values which were obtained by the evaluation of the relative

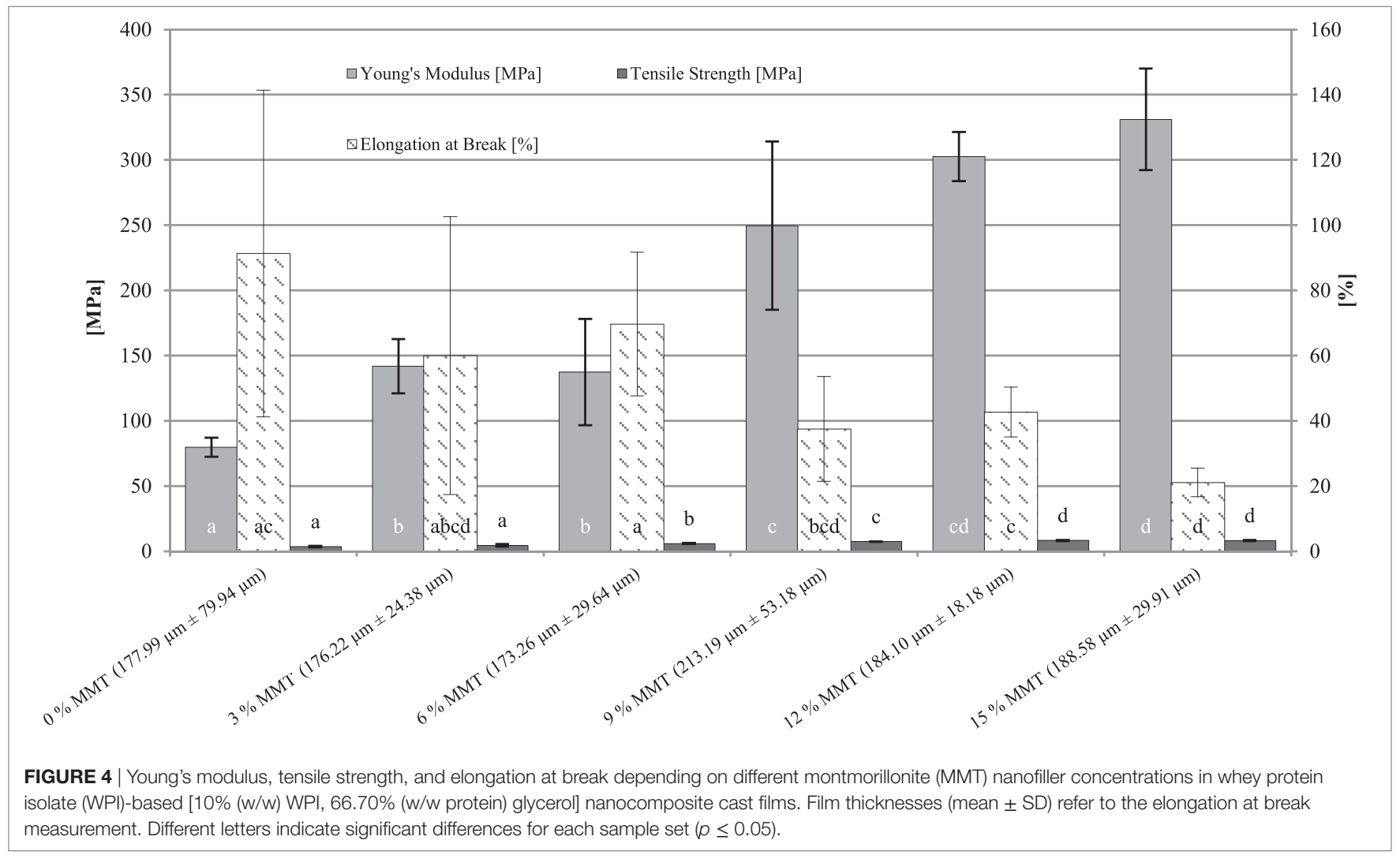




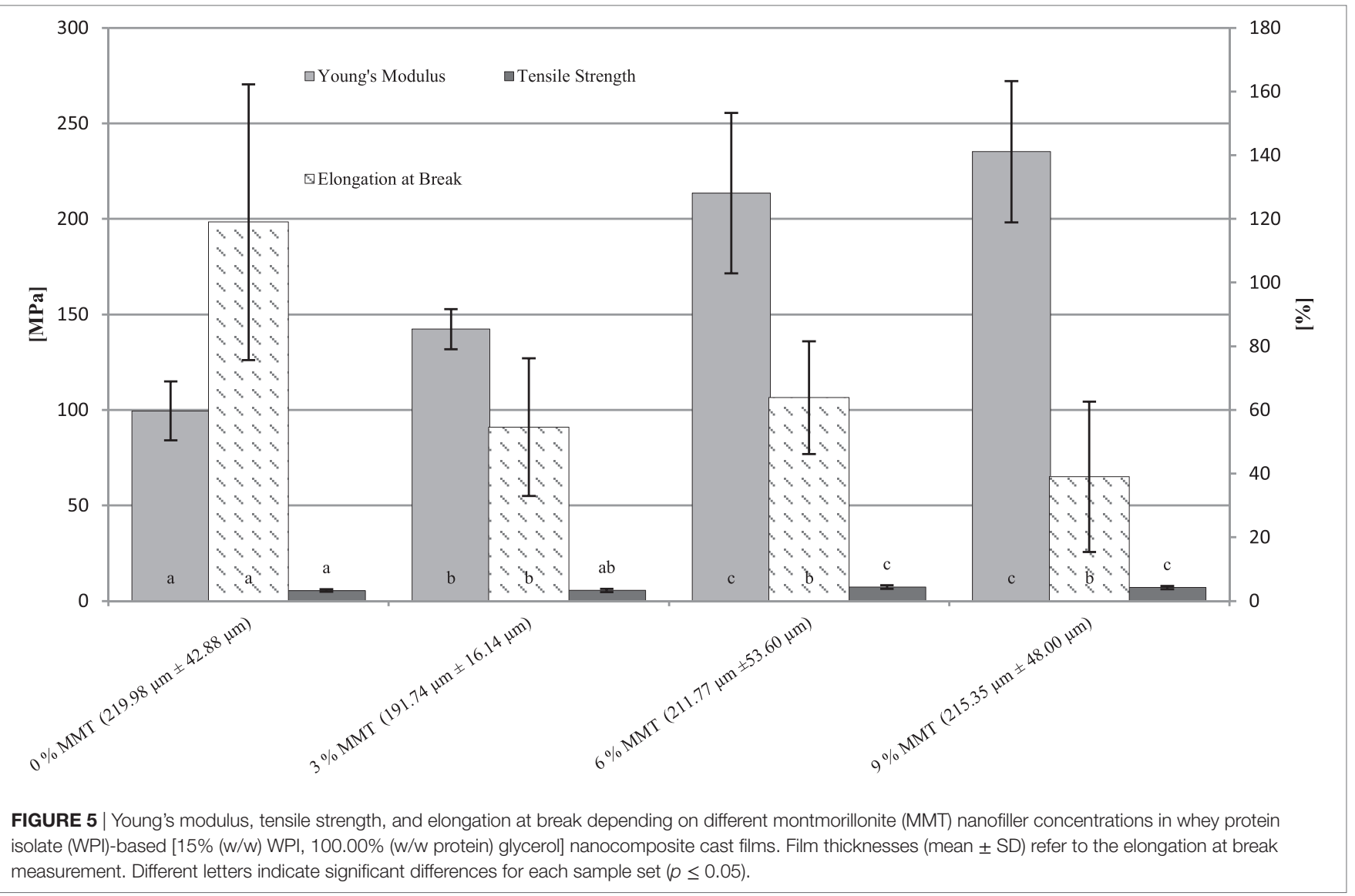

length change of the films are not standardized to the thickness of the film specimens. Respective film thicknesses regarding elongation at break measurement are shown in Figure 4.

For cast films with a protein loading of $15 \%(\mathrm{w} / \mathrm{w}) \mathrm{WPI}$ and $100.00 \%$ (w/w protein) glycerol, similar results were observed (Figure 5). In this case, as discussed earlier for the viscosity measurement, an addition of MMT was only possible up to a concentration of $9 \%$ (w/w protein) as the viscosity of the nanodispersion increases with increasing nanofiller content. Again, as for the films with $10 \%(\mathrm{w} / \mathrm{w})$ WPI and $66.70 \%$ (w/w protein) glycerol, a significant improvement of the YM could already be observed between the reference sample and 3\% (w/w protein) MMT. The best results regarding the improvement of the YM, again, were obtained at the highest nanofiller concentrations ( 6 and $9 \% \mathrm{w} / \mathrm{w})$ MMT, although these differences were not significantly $(p>0.05)$ different from each other. Similar results were also obtained for TS. The addition of the nanofiller starting from $6 \%$ (w/w protein) led to significant differences in TS. Regarding E\% values, the addition of $3 \%$ (w/w protein) MMT led to a significant $(p \leq 0.05)$ reduction of the $\mathrm{E} \%$ values by a factor of about 2 . A further addition of the nanofiller did not lead to significant changes of the elongation properties. Respective film thicknesses regarding the elongation at break measurement are shown in Figure 5.

The addition of nanoscale filler materials, e.g., MMTnanoplatelets, is a common method to increase the stiffness (YM) of polymeric matrices as widely described by composite theories
(Fornes and Paul, 2003; Lee and Paul, 2005). As expected, YM increased with increasing volume fraction of the nanofiller. Generally, the stiffness of polymeric materials compared to their respective reference matrix (without nanofiller) increases with increasing filler concentration as long as the nanofiller is sufficiently dispersed and a certain degree of exfoliation within the matrix is achieved (Utracki and Limited, 2004; Ait Hocine et al., 2008). Therefore, continuously increasing YM values can be understood as good indicators for sufficiently-dispersed and well-exfoliated nanofiller particles within the WPI matrix. These observations also suggest that a critical nanofiller concentration is not yet reached as reinforcing effects for nanocomposites with high filler loadings are reported to be in the range of the neat matrix or even lower due to decreased dispersion/exfoliation and aggregated or stacked nanofiller (Alexandre and Dubois, 2000; Sur et al., 2001; Mittal, 2009).

The addition of nanofillers into polymeric matrices can also increase film strength (TS) (Fornes et al., 2001) but, however, in contrast to YM, TS is a non-linear mechanical property which will decrease to values even lower than those of the neat matrix after a critical filler loading is exceeded (Zhou et al., 2009). The improvement of film strength (TS), in contrast to material stiffness (YM), is mainly governed by the effectiveness of the load transfer within the composite film, as film strength is determined at higher strains compared to YM values where the load transfer between matrix and reinforcing particle plays a crucial role (Mittal, 2009). As reported by Almasi et al. (2010), this improvement in 
the mechanical properties is mainly due to strong interfacial interactions between the matrix and the dispersed nanofiller via hydrogen bonding. Another explanation for the improvement of the TS values can be given by means of the free-volume theory. In addition to the reinforcement of the material due to sufficient interfacial interactions between matrix and filler, the nanofiller also acts as an anti-plasticizer in the WPI-based nanocomposite films. Due to this anti-plasticizer effect, a reduced free-volume and consequently more entangled polymer chains are caused whereby more stress can be supported by the films (Oymaci and Altinkaya, 2016). This may also explain the lowered extensibility of the nanocomposite films observed during the $\mathrm{E} \%$ measurement as more entangled polymer chains are less flexible. Consequently, contrary to YM and TS, material ductility of WPI-based nanocomposites, as shown by $\mathrm{E} \%$ measurement, generally decreases with increasing nanofiller content (Paul and Robeson, 2008). These findings are concurring with the findings of Zhou et al. (2009). They reported increased YM and TS values for $\mathrm{WPI}^{-\mathrm{TiO}_{2}}$ nanocomposite films compared to WPI-films without nanofiller addition. However, they also found that these properties (YM and TS) started to decline again when a critical $\mathrm{TiO}_{2}$ nanoparticle concentration $(>1 \%$ $\mathrm{w} / \mathrm{w})$ was exceeded. Regarding elongation at break (E\%) they generally observed decreasing values regardless of the nanofiller concentration. As a possible reason for the reduction of tensile properties they clearly identified inhomogeneous distribution and aggregation of $\mathrm{TiO}_{2}$ within the WPI-matrix due to relative polarity differences between the matrix and the nanoparticles (Zhou et al., 2009). On the basis of these findings, and, as mentioned earlier, the continuously increasing tensile values (YM and TS) found during this study, we assume that the nanofiller particles used in this study are sufficiently dispersed and well exfoliated. Comparable results were also found by Azevedo et al. (2015) and Hassannia-Kolaee et al. (2016b) for denatured WPI/MMT films, and Zolfi et al. (2014) for kefiran-WPI/MMT films.

\section{Effect of Plasticizer Type}

The effect of the plasticizer type could only be evaluated for glycerol-plasticized films as sorbitol-plasticized samples, caused by MMT addition, were too brittle to prepare samples for the tensile test. Therefore, only the reference samples, containing either glycerol or sorbitol, were evaluated. Table 4 shows the results of the plasticizer comparison. Generally, films plasticized with sorbitol were significantly $(p \leq 0.05)$ stiffer and stronger compared to glycerol-plasticized films. This observations are consistent with the findings of Shaw et al. (2002) who reported significantly lower YM and TS for WPI-films plasticized with glycerol compared to sorbitol at each plasticizer:protein ratio as well as with the findings of Chick and Ustunol (1998) who reported significantly lower TS for glycerol-plasticized films in lactic acid and rennet precipitated casein-based films. On the contrary, glycerol-plasticized films generally yielded significantly $(p \leq 0.05)$ higher values regarding elongation at break (E\%) which is also consistent with the literature (McHugh and Krochta, 1994; Chick and Ustunol, 1998; Shaw et al., 2002).

These observations can be explained by the ability of plasticizers to improve mechanical performance in protein-based films and coatings by increasing protein chain mobility. This is achieved by reducing protein-protein interactions as highly polar plasticizer molecules interfere with other polar-binding sites, e.g., polar amino acids or water molecules (Cuq et al., 1997). In addition, due to their relative high hygroscopicity (and relative differences in hygroscopicity between glycerol and sorbitol) (Shaw et al., 2002; Verbeek and van den Berg, 2010), polyol plasticizers cause increased sorption of water molecules from the surrounding environment which leads to an increased free-volume and consequently further increased protein chain mobility (Lieberman and Gilbert, 1973). Thus, the mechanical properties of WPI-based nanocomposite films may be further improved by the choice of a more compatible plasticizer type (or mixture) and concentration (McHugh and Krochta, 1994).

\section{Wetting Properties}

Protein-based edible films usually possess over high surface energies due to their hydrophilic nature which can be verified by low contact angles with hydrophilic fluids. The determination of the wetting behavior represents a key characteristic for protein-based film processing as it governs many packaging-related properties, e.g., sorption and transmission of moisture, adhesion, and printability. The contact angle measurement was conducted with either glycerol- or sorbitol-plasticized nanocomposite cast films (200 $\mu \mathrm{m}$ thickness).

It can be observed from Table 5 that in case of glycerolplasticized nanocomposite films, regardless of the increasing nanofiller loading, the SFE of the tested nanocomposite cast films remains nearly constant. Only for the highest filler loadings, a slight decline of the total SFE associated with a simultaneous decline of the polar fraction of the SFE by about $5 \mathrm{mN} \mathrm{m}^{-1}$ could

TABLE 4 | Young's modulus (YM), tensile strength (TS), and elongation at break (E\%) depending on different types of plasticizers (66.7\% w/w protein).

\begin{tabular}{lccc}
\hline Plasticizer type & YM (MPa) & TS (MPa) & E\% (\%) \\
\hline Glycerol & $79.72 \pm 7.39^{\mathrm{a}}$ & $3.54 \pm 0.63^{\mathrm{a}}$ & $91.32 \pm 50.13^{\mathrm{a}}$ \\
Sorbitol & $306.00 \pm 44.13^{\mathrm{b}}$ & $8.85 \pm 0.82^{\mathrm{b}}$ & $8.68 \pm 3.31^{\mathrm{b}}$
\end{tabular}

Different letters indicate significant differences for each sample set ( $p \leq 0.05)$. Film thicknesses (mean $\pm S D$ ) for the E\% measurement of glycerol- and sorbitol-plasticized films are $177.99 \pm 79.94$ and $181.71 \pm 35.40 \mu \mathrm{m}$, respectively.

TABLE 5 | Effect of an increasing montmorillonite (MMT) nanofiller-loading and varying plasticizer type (glycerol or sorbitol) on the disperse fraction, polar fraction, and total surface free energy (SFE) of WPI-based (10\% (w/w dispersion), $66.70 \%$ (w/w protein) plasticizer) nanocomposite cast films (200 $\mu \mathrm{m}$ thickness).

\begin{tabular}{llccccc}
\hline SFE (mN m & -1) & \multicolumn{5}{c}{ MMT\% (w/w protein) } \\
\cline { 2 - 7 } & \multicolumn{1}{c}{$\mathbf{0}$} & $\mathbf{3}$ & $\mathbf{6}$ & $\mathbf{9}$ & $\mathbf{1 2}$ & $\mathbf{1 5}$ \\
\hline & Glycerol & & & & \\
Disperse part & 20.5 & 20.3 & 18.6 & 20 & 19.9 & 20.2 \\
Polar part & 41.0 & 41.3 & 43.6 & 43.3 & 40.7 & 35.2 \\
Total SFE & 61.5 & 61.6 & 62.2 & 63.3 & 60.6 & 55.4 \\
& Sorbitol & & & & & \\
Disperse part & 20.5 & 24.7 & 25.0 & 21.4 & 22.6 & 22.3 \\
Polar part & 32.2 & 23.1 & 27.9 & 33.9 & 29.5 & 29.1 \\
Total SFE & 52.7 & 47.8 & 52.9 & 55.3 & 52.1 & 51.4
\end{tabular}


TABLE 6 | Results of the surface color testing for whey protein isolate (WPI)-based nanocomposite cast films with 10 and $15 \%$ (w/w) WPI and different montmorillonite (MMT)-nanoparticle loadings.

\begin{tabular}{|c|c|c|c|c|c|c|c|}
\hline \multirow[t]{2}{*}{ WPI\% (w/w dispersion) } & \multirow[t]{2}{*}{ MMT\% (w/w protein) } & \multicolumn{2}{|c|}{$L^{*}$} & \multicolumn{2}{|c|}{$a^{*}$} & \multicolumn{2}{|c|}{$b^{*}$} \\
\hline & & Gly & Sor & Gly & Sor & Gly & Sor \\
\hline \multirow[t]{6}{*}{10} & 0 & $93.99 \pm 0.12^{a}$ & $93.92 \pm 0.11^{a}$ & $-0.58 \pm 0.11^{a}$ & $-0.63 \pm 0.09^{a}$ & $2.33 \pm 0.49^{a}$ & $2.52 \pm 0.47^{a}$ \\
\hline & 3 & $93.12 \pm 0.17^{b}$ & $93.42 \pm 0.43^{a}$ & $-0.58 \pm 0.07^{b}$ & $-0.70 \pm 0.15^{a}$ & $4.24 \pm 0.42^{b}$ & $3.29 \pm 0.94^{a}$ \\
\hline & 6 & $92.46 \pm 0.18^{c}$ & $92.43 \pm 0.31^{b}$ & $-1.02 \pm 0.06^{c}$ & $-1.06 \pm 0.11^{b}$ & $5.36 \pm 0.38^{c}$ & $5.51 \pm 0.62^{b}$ \\
\hline & 9 & $92.40 \pm 0.12^{\circ}$ & $91.49 \pm 0.28^{c}$ & $-1.02 \pm 0.05^{c}$ & $-1.32 \pm 0.07^{c}$ & $5.35 \pm 0.30^{c}$ & $7.39 \pm 0.49^{c}$ \\
\hline & 12 & $90.83 \pm 0.31^{d}$ & $90.94 \pm 0.58^{\mathrm{cd}}$ & $-1.49 \pm 0.09^{d}$ & $-1.46 \pm 0.18^{\mathrm{cd}}$ & $8.75 \pm 0.74^{d}$ & $9.81 \pm 0.93^{d}$ \\
\hline & 15 & $90.21 \pm 0.22^{e}$ & $90.93 \pm 0.14^{d}$ & $-1.64 \pm 0.05^{e}$ & $-1.47 \pm 0.03^{d}$ & $10.36 \pm 0.44^{e}$ & $8.62 \pm 0.24^{d}$ \\
\hline \multirow[t]{4}{*}{15} & 0 & $94.13 \pm 0.01^{a}$ & $93.92 \pm 0.15^{a}$ & $-0.60 \pm 0.04^{a}$ & $-0.62 \pm 0.11^{a}$ & $2.28 \pm 0.20^{a}$ & $2.38 \pm 0.49^{a}$ \\
\hline & 3 & $93.26 \pm 0.05^{b}$ & $92.99 \pm 0.23^{b}$ & $-0.77 \pm 0.02^{b}$ & $-0.94 \pm 0.07^{b}$ & $3.65 \pm 0.19^{b}$ & $4.43 \pm 0.38^{b}$ \\
\hline & 6 & $92.31 \pm 0.27^{\circ}$ & $92.14 \pm 0.39^{\circ}$ & $-1.03 \pm 0.76^{c}$ & $-1.14 \pm 0.18^{b c}$ & $5.41 \pm 0.55^{c}$ & $5.86 \pm 0.78^{c}$ \\
\hline & 9 & $91.75 \pm 0.32^{\circ}$ & $92.67 \pm 0.02^{\mathrm{bc}}$ & $-1.22 \pm 0.09^{c}$ & $-1.00 \pm 0.09^{b c}$ & $6.80 \pm 0.64^{d}$ & $5.11 \pm 0.13^{c}$ \\
\hline
\end{tabular}

Different letters indicate significant differences for each sample set $(p \leq 0.05)$.

be detected. In case of sorbitol-plasticized nanocomposite cast films, again, the SFE, regardless of the addition of the nanofiller, remains nearly constant, although slight decreases of the polar part of the SFE (samples with 3 and $6 \% \mathrm{MMT}$ w/w protein) were observed. Generally, it can be stated that the SFE of glycerolplasticized films is generally higher than the SFE of sorbitolplasticized films, indicating that the wetting behavior is rather a function of the plasticizer type than the nanofiller concentration. Kokoszka et al. (2010) reported a strong dependency of the wetting behavior of WPI-based films toward the plasticizer. On the one hand, this can be attributed to the hygroscopic properties of the plasticizing substances which led to an increased moisture affinity of the hydrophilic matrix. Thereby glycerol possess over a higher ability to absorb and retain water molecules as it exhibits a higher hygroscopicity than sorbitol does (Shaw et al., 2002). This might be explained by its lower molecular weight as the hygroscopicity of polyols decreases as with rising molecular weight the tendency for crystallization increases (Furia, 1973; Shaw et al., 2002). And on the other hand, the strong influence of the plasticizer type may be explained by the molecular structure of the plasticizer molecules. Glycerol and sorbitol both are highly polar molecules consisting of 55.4\% hydrophilic groups in case of glycerol, and $56.0 \%$ hydrophilic groups in case of sorbitol (Verbeek and van den Berg, 2010). However, at equal mass fractions of the plasticizing molecules, glycerol could be responsible for an increased polar fraction and consequently an increased SFE as due to its lower molecular weight of $92 \mathrm{~g} \mathrm{~mol}^{-1}$, compared to $182 \mathrm{~g} \mathrm{~mol}^{-1}$ for sorbitol, a greater number of glycerol molecules are present in the nanocomposites. Similar results were observed for nanocomposite cast films with an initial protein content of $15 \%(\mathrm{w} / \mathrm{w})$ and $100.00 \%$ plasticizer (glycerol or sorbitol).

\section{Optical Properties}

The visual appearance of WPI-based cast films and its nanocomposites was determined using the CIE-Lab color-space. Surface color is an important property of protein-based films and coatings as for food packaging applications, e.g., as gasbarrier coating in multilayer applications, as discolorations can negatively affect consumer acceptance. The results of the surface color measurement are shown in Table 6. As the used
MMT-nanoparticles display a yellowish color attention is particularly paid to color-shifts toward a yellowish hue $\left(+b^{\star}\right.$-values, as this characteristic property is expected to increase with increasing nanofiller content). The incorporation of nanofillers into WPI-based nanocomposite cast films was accompanied by decreasing $L^{\star}$-values (indicating reduced brightness), decreasing $-a^{*}$-values (indicating a color shift into greenish hues), and, as expected, increasing $+b^{\star}$-values (indicating the expected shift to a yellowish hue). These results are concurring with the study of Sothornvit et al. (2010) for WPI-based organoclay composite films and Echeverría et al. (2014) for incorporating MMT into soy protein isolate-based nanocomposite films. As the color of the nanocomposite films in this study, regardless of MMT-loading and increased $+b^{\star}$-value did not change considerably compared to the reference samples without addition of MMT nanofiller we assume that the nanoparticles in this study are sufficiently dispersed and exhibit good compatibility with the WPI-matrix. The comparison between the two plasticizers, sorbitol or glycerol, did not show considerable effects on the surface color properties of the tested films.

\section{CONCLUSION}

Naturally occurring inorganic MMT nanoplatelets were successfully dispersed in WPI-based matrices. Their high hydrophilicity and abundant functional hydroxyl groups and other oxygencontaining functional groups gave rise to the excellent compatibility and strong interactions via hydrogen bonding with the hydrophilic protein-plasticizer matrix.

As a result, barrier properties of WPI-based nanocomposites (WVTR and OP) improved with increasing nanofiller loadings. Thereby, sorbitol-plasticized nanocomposites generally exhibited better barrier properties compared to glycerol-plasticized nanocomposites. In case of WVTR measurement, the high hygroscopicity of glycerol-plasticized nanocomposites led to highly deviating film thicknesses that prevented a determination of the WVTR. Therefore, glycerol should be either replaced by a less hygroscopic plasticizer or the measuring conditions (humidity gradient) should be adjusted. These findings are supported by the results of the plasticizer comparison during mechanical testing. 
However, based on the low extensibility of sorbitol-plasticized cast films (reference matrix) and the general difficulties in preparing cast films from sorbitol-plasticized nanocomposites, it might be a better strategy to apply mixtures of glycerol and sorbitol instead of single-use to benefit from the specific properties of both plasticizers. In addition, tensile tests revealed that with increasing filler loadings the material stiffness (YM) and the TS continuously increased. We expect that a critical nanofiller loading is not yet exceeded as values for film strength (TS), a non-linear mechanical characteristic, are expected to decline to values in the range of the neat matrix or even below upon a critical filler loading. However, attention must be paid to film flexibility, as material ductility generally declines with increasing nanofiller loading. Optical evaluation confirmed that the addition of MMT nanofillers, although brightness decreased and color shifted toward yellowish shades, only had minor impact on the general appearance of the films. Furthermore, optical appearance of the films substantiates our hypothesis that the nanoplatelets are uniformly dispersed and well exfoliated within the biopolymer matrix.

These findings suggest that a further addition of MMT nanoplatelets into WPI-based nanocomposite dispersions can be realized which could lead to significantly enhanced technofunctional properties such as barrier properties and mechanical performance. Moreover, constantly increasing viscosities and shear-thinning flow behavior suggests that the nanoplatelets are well dispersed and exfoliated within the continuous matrix, which also supports good compatibility between the hydrophilic nanoplatelets and biopolymer.

To conclude, based on the findings of this study, the addition of natural MMT nanofillers into native WPI-based matrices to form nanocomposite films and coatings with higher filler loadings compared to the addition of filler materials into previously denatured matrices is an effective strategy to further enhance the technofunctional properties of these films. However, WPI-based

\section{REFERENCES}

Aït Hocine, N., Médéric, P., and Aubry, T. (2008). Mechanical properties of polyamide-12 layered silicate nanocomposites and their relations with structure. Polym. Test. 27, 330-339. doi:10.1016/j.polymertesting.2007.12.002

Alexandre, M., and Dubois, P. (2000). Polymer-layered silicate nanocomposites: preparation, properties and uses of a new class of materials. Mater. Sci. Eng. $R$ Rep. 28, 1-63. doi:10.1016/S0927-796X(00)00012-7

Almasi, H., Ghanbarzadeh, B., and Entezami, A. A. (2010). Physicochemical properties of starch-CMC-nanoclay biodegradable films. Int. J. Biol. Macromol. 46, 1-5. doi:10.1016/j.ijbiomac.2009.10.001

Arora, A., and Padua, G. W. (2010). Review: nanocomposites in food packaging. J. Food Sci. 75, R43-R49. doi:10.1111/j.1750-3841.2009.01456.x

Azevedo, V. M., Dias, M. V., Borges, S. V., Costa, A. L. R., Silva, E. K., Medeiros, ÉA. A., et al. (2015). Development of whey protein isolate bio-nanocomposites: effect of montmorillonite and citric acid on structural, thermal, morphological and mechanical properties. Food Hydrocolloids 48, 179-188. doi:10.1016/j. foodhyd.2015.02.014

Bharadwaj, R. K. (2001). Modeling the barrier properties of polymer-layered silicate nanocomposites. Macromolecules 34, 9189-9192. doi:10.1021/ ma010780b

Bharadwaj, R. K., Mehrabi, A. R., Hamilton, C., Trujillo, C., Murga, M., Fan, R., et al. (2002). Structure-property relationships in cross-linked polyester-clay nanocomposites. Polymer 43, 3699-3705. doi:10.1016/ S0032-3861(02)00187-8 nanocomposites are still poor moisture barriers which can mainly be attributed to the high amounts of plasticizer necessary to ensure sufficient flexibility and overcome brittleness as well as to their hydrophilic nature. As suggested by the findings of this study, WPI-based nanocomposite films and coatings hold great potential to replace fossil-based packaging materials for at least certain applications such as oxygen barriers as part of multilayer flexible packaging films in food packaging applications but, however, further research is necessary to overcome existing drawbacks.

\section{AUTHOR CONTRIBUTIONS}

All authors contributed, edited, and wrote the paper.

\section{ACKNOWLEDGMENTS}

The authors sincerely thank Elodie Bugnicourt, coordinator of the below stated project, from IRIS, Castelldefels, Barcelona, Spain for the support and inputs provided. The authors also thank Maria Jordá, Eva Araque, Adelaida Prieto, Marta Lara, and Juan Antonio Maciá Agulló from ITENE - Packaging, Transport \& Logistics Research Center, Valencia, Spain for providing the montmorillonite-based nanodispersions. This work was supported by the German Research Foundation (DFG) and the Technical University of Munich (TUM) in the framework of the Open Access Publishing Program. The authors thank the DFG and TUM for their support.

\section{FUNDING}

This project has received funding from the European Union's Horizon 2020 research and innovation programme under grant agreement No 686116. For more information, refer to http:// optinanopro.eu/.

Binder, K., Granick, S., de Gennes, P. G., Giannelis, E. P., Grest, G. S., Hervet, H., et al. (2003). Polymers in Confined Environments. Berlin, Heidelberg: Springer.

Chick, J., and Ustunol, Z. (1998). Mechanical and barrier properties of lactic acid and rennet precipitated casein-based edible films. J. Food Sci. 63, 1024-1027. doi:10.1111/j.1365-2621.1998.tb15846.x

Choi, W. J., Kim, H. J., Yoon, K. H., Kwon, O. H., and Hwang, C. I. (2006). Preparation and barrier property of poly(ethylene terephthalate)/clay nanocomposite using clay-supported catalyst. J. Appl. Polym. Sci. 100, 4875-4879. doi:10.1002/app. 23268

Cuq, B., Gontard, N., Aymard, C., and Guilbert, S. (1997). Relative humidity and temperature effects on mechanical and water vapor barrier properties of myofibrillar protein-based films. Polym. Gels Netw. 5, 1-15. doi:10.1016/ S0966-7822(96)00026-3

Dean, K., Yu, L., and Wu, D. Y. (2007). Preparation and characterization of melt-extruded thermoplastic starch/clay nanocomposites. Compos. Sci. Technol. 67, 413-421. doi:10.1016/j.compscitech.2006.09.003

DIN. (1998). Bestimmung der Gasdurchlässigkeit. Teil 3: Sauerstoffspezifisches Trägergas-Verfahren zurMessung an Kunststoff-Folien und Kunststoff-Formteilen. DIN 53380-3. D. I. f. N. e.V. Berlin: Deutsches Institut für Normung e.V.

DIN. (2001). Bestimmung der Wasserdampfdurchlässigkeit. Teil 1: Gravimetrisches Verfahren. DIN 53122-1. D. I. f. N. e.V. Berlin: Deutsches Institut für Normung e.V.

DIN. (2012). Kunststoffe - Bestimmung der Zugeigenschaften. DIN EN ISO 527-1. D. I. f. N. e.V. Berlin: Deutsches Institut für Normung e.V. 
Echeverría, I., Eisenberg, P., and Mauri, A. N. (2014). Nanocomposites films based on soy proteins and montmorillonite processed by casting. J. Memb. Sci. 449, 15-26. doi:10.1016/j.memsci.2013.08.006

Fornes, T., and Paul, D. (2003). Modeling properties of nylon 6/clay nanocomposites using composite theories. Polymer 44, 4993-5013. doi:10.1016/ S0032-3861(03)00471-3

Fornes, T. D., Yoon, P. J., Keskkula, H., and Paul, D. R. (2001). Nylon 6 nanocomposites: the effect of matrix molecular weight. Polymer 42, 9929-9940. doi:10.1016/S0032-3861(01)00552-3

Furia, T. E. (1973). CRC Handbook of Food Additives, 2nd Edn. Boca Raton, FL: Taylor \& Francis.

Geraldo De, F. M., Dos Santos, H. K., and Fabiana De, O. F. (2009). Rheological analysis of water clay compositions in order to investigate mudflows developing in canals. J. Braz. Soc. Mech. Sci. Eng. 31, 64-74. doi:10.1590/ S1678-58782009000100010

Giannelis, E. P. (1996). Polymer layered silicate nanocomposites. Adv. Mater. Weinheim 8, 29-35. doi:10.1002/adma.19960080104

Hammann, F., and Schmid, M. (2014). Determination and quantification of molecular interactions in protein films: a review. Materials (Basel) 7, 7975-7996. doi:10.3390/ma7127975

Hassannia-Kolaee, M., Khodaiyan, F., Pourahmad, R., and Shahabi-Ghahfarrokhi, I. (2016a). Development of ecofriendly bionanocomposite: whey protein isolate/pullulan films with nano-SiO 2 . Int. J. Biol. Macromol. 86, 139-144. doi:10.1016/j.ijbiomac.2016.01.032

Hassannia-Kolaee, M., Khodaiyan, F., and Shahabi-Ghahfarrokhi, I. (2016b). Modification of functional properties of pullulan-whey protein bionanocomposite films with nanoclay. J. Food Sci. Technol. 53, 1294-1302. doi:10.1007/ s13197-015-1778-3

Hedenqvist, M. S., Backman, A., Gällstedt, M., Boyd, R. H., and Gedde, U. W. (2006). Morphology and diffusion properties of whey/montmorillonite nanocomposites. Compos. Sci. Technol. 66, 2350-2359. doi:10.1016/j.compscitech.2005.11.026

Hong, S.-I., and Krochta, J. M. (2006). Oxygen barrier performance of whey-protein-coated plastic films as affected by temperature, relative humidity, base film and protein type. J. Food Eng. 77, 739-745. doi:10.1016/j.jfoodeng.2005.07.034

Huang, H.-D., Zhou, S.-Y., Ren, P.-G., Ji, X., and Li, Z.-M. (2015). Improved mechanical and barrier properties of low-density polyethylene nanocomposite films by incorporating hydrophobic graphene oxide nanosheets. RSC Adv. 5, 80739-80748. doi:10.1039/C5RA12694K

Kadam, D. M., Thunga, M., Wang, S., Kessler, M. R., Grewell, D., Lamsal, B., et al. (2013). Preparation and characterization of whey protein isolate films reinforced with porous silica coated titania nanoparticles. J. Food Eng. 117, 133-140. doi:10.1016/j.jfoodeng.2013.01.046

Kim, H., Abdala, A. A., and Macosko, C. W. (2010). Graphene/polymer nanocomposites. Macromolecules 43, 6515-6530. doi:10.1021/ma100572e

Kokoszka, S., Debeaufort, F., Lenart, A., and Voilley, A. (2010). Water vapour permeability, thermal and wetting properties of whey protein isolate based edible films. Int. Dairy J. 20, 53-60. doi:10.1016/j.idairyj.2009.07.008

Krishnamoorti, R., Ren, J., and Silva, A. S. (2001). Shear response of layered silicate nanocomposites. J. Chem. Phys. 114, 4968-4973. doi:10.1063/1.1345908

Langowski, H.-C. (2008). Permeation of Gases and Condensable Substances through Monolayer and Multilayer Structures. Weinheim: Plastic Packaging, Wiley-VCH Verlag GmbH \& Co. KGaA, 297-347.

Lee, K. Y., and Paul, D. R. (2005). A model for composites containing three-dimensional ellipsoidal inclusions. Polymer 46, 9064-9080. doi:10.1016/j. polymer.2005.06.113

Li, Y., Jiang, Y., Liu, F., Ren, F., Zhao, G., and Leng, X. (2011). Fabrication and characterization of $\mathrm{TiO}_{2} /$ whey protein isolate nanocomposite film. Food Hydrocolloids 25, 1098-1104. doi:10.1016/j.foodhyd.2010.10.006

Lieberman, E. R., and Gilbert, S. G. (1973). Gas permeation of collagen films as affected by crosslinkage, moisture, and plasticizer content. J. Polym. Sci. C Polym. Symp. 41, 33-43.

Manias, E., Hadziioannou, G., and ten Brinke, G. (1996). Inhomogeneities in sheared ultrathin lubricating films. Langmuir 12, 4587-4593. doi:10.1021/ la950902r

Matijašić, G., and Glasnović, A. (2002). Influence of dispersed phase characteristics on rheological behavior of suspensions. Chem. Biochem. Eng. Q. 16, $165-172$.

McAdam, C. P., Hudson, N. E., Liggat, J. J., and Pethrick, R. A. (2008). Synthesis and characterization of nylon 6/clay nanocomposites prepared by ultrasonication and in situ polymerization. J. Appl. Polym. Sci. 108, 2242-2251. doi:10.1002/ app. 25599

McClements, D. J., and Keogh, M. K. (1995). Physical properties of cold-setting gels formed from heat-denatured whey protein isolate. J. Sci. Food Agric. 69, 7-14. doi:10.1002/jsfa.2740690103

McHugh, T. H., and Krochta, J. M. (1994). Sorbitol-plasticized vs glycerol-plastizied whey-protein edible films - integrated oxygen permeability and tensile property evaluation. J. Agric. Food Chem. 42, 841-845. doi:10.1021/jf00040a001

Menges, G. (2002). Werkstoffkunde Kunststoffe, Hanser Fachbuchverlag. Munich: Hanser Fachbuchverlag.

Miller, K. S., and Krochta, J. M. (1997). Oxygen and aroma barrier properties of edible films: a review. Trends Food Sci. Technol. 8, 228-237. doi:10.1016/ S0924-2244(97)01051-0

Mittal, V. (2009). Optimization of Polymer Nanocomposite Properties. Weinheim: Wiley.

Mittal, V. (2012). Characterization Techniques for Polymer Nanocomposites. John Wiley and Sons Ltd.

Müller, K., Jesdinszki, M., and Schmid, M. (2017). Modification of functional properties of whey protein isolate nanocomposite films and coatings with nanoclays. J. Nanomater. 2017:6039192. doi:10.1155/2017/6039192

Ninnemann, K. W. (1968). "Measurements of physical properties of flexible films," in Science and Technology of Polymer Films, ed. O. J. Sweeting (London: Interscience), 546-649.

Oguzlu, H., and Tihminlioglu, F. (2010). Preparation and Barrier Properties of Chitosan-Layered Silicate Nanocomposite Films. Weinheim: Macromolecular Symposia, Wiley Online Library.

Oymaci, P., and Altinkaya, S. A. (2016). Improvement of barrier and mechanical properties of whey protein isolate based food packaging films by incorporation of zein nanoparticles as a novel bionanocomposite. Food Hydrocolloids 54, 1-9. doi:10.1016/j.foodhyd.2015.08.030

Park, H.-M., Li, X., Jin, C.-Z., Park, C.-Y., Cho, W.-J., and Ha, C.-S. (2002). Preparation and properties of biodegradable thermoplastic starch/clay hybrids. Macromol. Mater. Eng. 287, 553-558. doi:10.1002/1439-2054(20020801)287:8<553::AIDMAME553>3.0.CO;2-3

Paul, D. R., and Robeson, L. M. (2008). Polymer nanotechnology: nanocomposites. Polymer 49, 3187-3204. doi:10.1016/j.polymer.2008.04.017

Pérez-Gago, M. B., Nadaud, P., and Krochta, J. M. (1999). Water vapor permeability, solubility, and tensile properties of heat-denatured versus native whey protein films. J. Food Sci. 64, 1034-1037. doi:10.1111/j.1365-2621.1999.tb12276.x

Petersson, L., and Oksman, K. (2006). Biopolymer based nanocomposites: comparing layered silicates and microcrystalline cellulose as nanoreinforcement. Compos. Sci. Technol. 66, 2187-2196. doi:10.1016/j.compscitech.2005.12.010

Ray, S., Quek Siew, Y., Easteal, A., and Chen Xiao, D. (2006). The potential use of polymer-clay nanocomposites in food packaging. Int. J. Food Eng. 2. doi:10.2202/1556-3758.1149

Rhim, J.-W., Hong, S.-I., and Ha, C.-S. (2009). Tensile, water vapor barrier and antimicrobial properties of PLA/nanoclay composite films. LWT Food Sci. Technol. 42, 612-617. doi:10.1016/j.lwt.2008.02.015

Robertson, G. L. (2006). Food Packaging: Principles and Practice. Boca Raton, FL: Taylor \& Francis/CRC Press.

Schmid, M. (2013). Properties of cast films made from different ratios of whey protein isolate, hydrolysed whey protein isolate and glycerol. Materials (Basel) 6, 3254. doi:10.3390/ma6083254

Schmid, M., Dallmann, K., Bugnicourt, E., Cordoni, D., Wild, F., Lazzeri, A., et al. (2012). Properties of whey protein coated films and laminates as novel recyclable food packaging materials with excellent barrier properties. Int. J. Polym. Sci. 2012, 7. doi:10.1155/2012/562381

Schmid, M., Noller, K., Wild, F., and Bugnicourt, E. (2013). Whey Protein Coated Films. WO/2013/014493.

Schmid, M., Reichert, K., Hammann, F., and Stäbler, A. (2015). Storage time-dependent alteration of molecular interaction-property relationships of whey protein isolate-based films and coatings. J. Sci. Mater. 50, 4396-4404. doi:10.1007/ s10853-015-8994-0

Shaw, N. B., Monahan, F. J., O'Riordan, E. D., and O'Sullivan, M. (2002). Physical properties of WPI films plasticized with glycerol, xylitol, or sorbitol. J. Food Sci. 67, 164-167. doi:10.1111/j.1365-2621.2002.tb11377.x

Sinha Ray, S., and Okamoto, M. (2003). Polymer/layered silicate nanocomposites: a review from preparation to processing. Prog. Polym. Sci. 28, 1539-1641. doi:10.1016/j.progpolymsci.2003.08.002 
Sorrentino, A., Gorrasi, G., and Vittoria, V. (2007). Potential perspectives of bio-nanocomposites for food packaging applications. Trends Food Sci. Technol. 18, 84-95. doi:10.1016/j.tifs.2006.09.004

Sothornvit, R., Hong, S.-I., An, D. J., and Rhim, J.-W. (2010). Effect of clay content on the physical and antimicrobial properties of whey protein isolate/organo-clay composite films. LWT Food Sci. Technol. 43, 279-284. doi:10.1016/j. lwt.2009.08.010

Sothornvit, R., Rhim, J.-W., and Hong, S.-I. (2009). Effect of nano-clay type on the physical and antimicrobial properties of whey protein isolate/clay composite films. J. Food Eng. 91, 468-473. doi:10.1016/j.jfoodeng.2008.09.026

Sur, G. S., Sun, H. L., Lyu, S. G., and Mark, J. E. (2001). Synthesis, structure, mechanical properties, and thermal stability of some polysulfone/organoclay nanocomposites. Polymer 42, 9783-9789. doi:10.1016/S0032-3861(01)00527-4

Tunc, S., Angellier, H., Cahyana, Y., Chalier, P., Gontard, N., and Gastaldi, E. (2007). Functional properties of wheat gluten/montmorillonite nanocomposite films processed by casting. J. Memb. Sci. 289, 159-168. doi:10.1016/j. memsci.2006.11.050

Utracki, L. A. (2004). Clay-containing Polymeric Nanocomposites. Shawbury: Rapra Technology Limited.

Verbeek, C. J. R., and van den Berg, L. E. (2010). Extrusion processing and properties of protein-based thermoplastics. Macromol. Mater. Eng. 295, 10-21. doi:10.1002/mame.200900167

Visakh, P. M., and Sigrid, L. (2016). Polyethylene-Based Biocomposites and Bionanocomposites. Hoboken, NJ: John Wiley \& Sons Inc. and Beverly, MA: Scrivener Publishing LLC.

Wakai, M., and Almenar, E. (2015). Effect of the presence of montmorillonite on the solubility of whey protein isolate films in food model systems with different compositions and pH. Food Hydrocolloids 43, 612-621. doi:10.1016/j. foodhyd.2014.07.022

Weizman, O., Dotan, A., Nir, Y., and Ophir, A. (2017). Modified whey protein coatings for improved gas barrier properties of biodegradable films. Polym. Adv. Technol. 28, 261-270. doi:10.1002/pat.3882
Yang, Y., Zhu, Z.-K., Yin, J., Wang, X.-Y., and Qi, Z.-E. (1999). Preparation and properties of hybrids of organo-soluble polyimide and montmorillonite with various chemical surface modification methods. Polymer 40, 4407-4414. doi:10.1016/S0032-3861(98)00675-2

Yoo, B. M., Shin, H. J., Yoon, H. W., and Park, H. B. (2014). Graphene and graphene oxide and their uses in barrier polymers. J. Appl. Polym. Sci. 131:39628. doi:10.1002/app.39628

Zeng, Q. H., Yu, A. B., Lu, G. Q., and Paul, D. R. (2005). Clay-based polymer nanocomposites: research and commercial development. J. Nanosci. Nanotechnol. 5, 1574-1592. doi:10.1166/jnn.2005.411

Zhou, J. J., Wang, S. Y., and Gunasekaran, S. (2009). Preparation and characterization of whey protein film incorporated with $\mathrm{TiO}_{2}$ nanoparticles. J. Food Sci. 74, N50-N56. doi:10.1111/j.1750-3841.2009.01270.x

Zink, J., Wyrobnik, T., Prinz, T., and Schmid, M. (2016). Physical, chemical and biochemical modifications of protein-based films and coatings: an extensive review. Int. J. Mol. Sci. 17, 1376. doi:10.3390/ijms17091376

Zolfi, M., Khodaiyan, F., Mousavi, M., and Hashemi, M. (2014). The improvement of characteristics of biodegradable films made from kefiran-whey protein by nanoparticle incorporation. Carbohydr. Polym. 109, 118-125. doi:10.1016/j. carbpol.2014.03.018

Conflict of Interest Statement: The authors declare that the research was conducted in the absence of any commercial or financial relationships that could be construed as a potential conflict of interest.

Copyright (C) 2017 Schmid, Merzbacher, Brzoska, Müller and Jesdinszki. This is an open-access article distributed under the terms of the Creative Commons Attribution License (CC BY). The use, distribution or reproduction in other forums is permitted, provided the original author(s) or licensor are credited and that the original publication in this journal is cited, in accordance with accepted academic practice. No use, distribution or reproduction is permitted which does not comply with these terms. 